\title{
The Effect of Internal Capital Shocks on Manager \\ Behavior: Evidence from Changes in ERISA Pension \\ Accounting Rules
}

\author{
by \\ Michael Dambra \\ Submitted in Partial Fulfillment of the \\ Requirements for the Degree \\ Doctor of Philosophy
}

Supervised by Professor Shane M. Heitzman and Professor Joanna S. Wu

Business Administration

Simon Business School

University of Rochester

Rochester, New York

2014 


\section{Dedication}

To my children: Vincent, James, and Mia who made it fun to come home after an unsuccessful day in the lab and to my wife, Sara, who nearly single-handedly raised our children and always supported my doctoral studies for the past six years. I love you. 


\section{Biographical Sketch}

The author was born and raised in Rochester, New York. He attended St. Bonaventure University, and graduated with a Bachelor of Business Administration degree in Accounting and a Masters in Business Administration concentrated in Accounting and Finance. After graduate studies, he worked as a Senior Associate at KPMG and a Valuation Analyst at Empire Valuation Consultants, Inc. He began doctoral studies in Accounting at the University of Rochester in 2008. He was awarded a doctoral student fellowship from 2008 to 2012 and earned a Master of Science in Business Administration from the University of Rochester in 2011. He pursued his research in Accounting under the direction of Shane M. Heitzman and Joanna Wu. He is registered as a Certified Public Accountant in the State of New York.

The following publications or publications in review were a result of work conducted during doctoral study:

Dambra, M., Wasley, C.E., and Wu, J.S. 2013. Soft-Talk Management Cash Flow Forecasts: Bias, Quality, and Stock Price Effects. Contemporary Accounting Research 30: 607-644.

Dambra, M., Field, L.C., and Gustafson, M. 2014. The JOBS Act and IPO Volume: Evidence that Disclosure Costs Affect the IPO Decision. Revising for Second Round Submission at the Journal of Financial Economics. 


\section{Acknowledgements}

I am greatly indebted to Shane Heitzman, Joanna Wu, and Ed Owens for their invaluable guidance in the development of this paper. Shane Heitzman and Joanna Wu assisted me in converting a peculiar regulatory shock into an economic question and Ed Owens helped me place the paper in the literature and taught me how to pitch a paper. I learned so much through the process and their feedback was irreplaceable. I also need to thank my colleagues Mihail Velikov and Matthew Gustafson for pushing me to go forward when I wanted to quit, and of course, telling me to "Toughen' Up". It was the kick in the pants that I needed. I also thank Rajiv Banker, Jacquelyn Gillette, Feng Gu, Matt Gustafson, Rachel Hayes, Jaewoo Kim, Bill Kross, Melissa Lewis, Robert Novy-Marx, Marlene Plumlee, Cliff Smith, Stephen Stubben, Claudia Qi, Charles Wasley, Dave Weber, Toni Whited, Mike Willenborg, Jerry Zimmerman and seminar participants at Temple University, the University of Buffalo, the University of Connecticut, and the University of Utah for helpful comments and suggestions. 


\begin{abstract}
Academics, trade groups, and pension plan sponsors argue that pension obligations constrict investment and lead to economic inefficiencies. Exploiting a 2012 change in the ERISA pension accounting rules that decreased mandatory pension contributions, my results suggest that recipients of pension funding relief increase shareholder payouts. Shareholder payouts comprise 15 to 21 percent of the pension funding relief subsequent to the accounting rule change. I find mixed evidence that the cash flows from the reduction of mandatory contributions under MAP-21 have an immediate effect on investment. The investment effect is concentrated in firms with the highest investment opportunity sets and firms that can more easily reverse investment if the temporary pension rule change reverts. In addition, recipients of pension funding relief retain more cash after the rule change. This effect is strongest for firms with higher cash flow uncertainty and for firms without credit ratings, consistent with managers retaining cash in anticipation of future financing needs. The association between shareholder payouts and pension obligations is robust to utilizing alternative ERISA accounting rule changes that predicated the 2012 rule change.
\end{abstract}




\section{Contributors and Funding Sources}

This work was supervised by a dissertation committee consisting of Professors Shane M.

Heitzman, Joanna S. Wu, and Edward L. Owens of the Department of Accounting. All work for the dissertation was completed independently by the student. Graduate study was supported by a doctoral student fellowship from the University of Rochester. 


\section{Table of Contents}

Dedication $\quad$ ii

Biographical Sketch $\quad$ iii

Acknowledgements $\quad$ iv

Abstract $\quad$ V

Contributors and Funding Sources $\quad$ vi

1. Introduction 1

2. Literature Review 6

3. Institutional Background 9

$\begin{array}{lll}\text { 3.0. Setting } & 9\end{array}$

3.1. Pension Funding Rules under the Pension Protection Act 11

3.2. Legislative History and Pension Funding Rules under MAP-21 12

4. Data and Research Design 15

4.0. Data Description 15

4.1. Identification Strategy 16

4.2. MAP-21 Event Study 18

4.3. Empirical Design of Investment and Payout Policy Regressions 21

4.4. Empirical Design of Cross-sectional Analyses 25

5. Descriptive Statistics 29

6. Empirical Results 30

6.0. Univariate Analysis 30

6.1. Multivariate Results 31 
6.2. Cross-sectional Results 34

6.3. Robustness Test 37

7. Conclusion 41

$\begin{array}{ll}\text { References } & 43\end{array}$

Appendix A: Calculation of the Shortfall Contribution 47

Appendix B: Legislative History of MAP-21 49

Appendix C: Validation of Funding Relief Proxies 50

Appendix D: Variable Definitions $\quad 53$ 


\section{List of Tables}

Table 1: Abnormal Stock Returns from Pension Funding Relief 55

Table 2: Descriptive Statistics $\quad 57$

Table 3: Pension Funding Difference-in-Differences 59

Table 4: Pension Funding Relief (Underfund) Multivariate Analysis 60

Table 5: Pension Funding Relief (MC) Multivariate Analysis $\quad 61$

Table 6: The Effect of Pension Funding Relief of Cash Holdings 62

Table 7: Pension Funding Relief and Financial Constraints 63

Table 8: Pension Funding Relief, Secondary Market Liquidity, and Growth Options 64

Table 9: Alternative Pension Funding Relief Shocks 66 


\section{List of Figures}

Figure 1: Pension Plan Funding and Pension Contributions 67

$\begin{array}{ll}\text { Figure 2: ERISA Discount Rates } & 68\end{array}$

Figure 3: Expected Change in Mandatory Contributions due to MAP-21 69

Figure 4: Example of MAP-21 Annual Funding Notice $\quad 70$

Figure 5: Pension Contributions, Capital Expenditures, and Stock Repurchases by Quarter (Hi UF sample) 


\section{Introduction}

An unsettled question in corporate finance is how changes in internal capital influence corporate investment. Theory suggests that asymmetric information between insiders and capital providers creates a wedge between the cost of internal and external capital. Difficulties that a firm encounters in obtaining outside financing then affect its real investment decisions. The early empirical literature finds an association between internal capital and investment (e.g., Fazzari et al., 1988). However, this association may be spurious if there is correlation between changes in internal capital and unobservable variables that capture investment profitability (e.g., Kaplan and Zingales, 1997, Bakke and Whited, 2012). For example, new technology that expands a firm's product market (e.g., Apple's iPad) may simultaneously increase investment and internal capital. An ideal approach to investigate the causal link between cash flow changes and investment requires an exogenous shock to a firm's internal capital independent of its investment opportunity set.

Two recent papers, Rauh (2006) and Bakke and Whited (2012), use pension funding rules to identify exogenous changes in cash outflows. Defined benefit pension plan sponsors are required to contribute an amount that is a function of the difference between their pension assets and the present value of their pension liabilities. Rauh (2006) finds that investment decreases as mandatory pension contributions increase using the entire distribution of firms with defined benefit plans. Bakke and Whited (2012) analyze observations immediately above or below Employee Retirement Income Security Act ("ERISA") pension funding thresholds where jumps in mandatory contributions 
occur. Assuming some randomness to firms being above or below funding thresholds, Bakke and Whited (2012) avoid concerns regarding the endogeneity of a firm's pension funding status. They find no evidence of a change in capital expenditures, but find that employment and research and development increase if pension funding is above certain thresholds. Bakke and Whited (2012) caveat that their findings may not be generalizable to observations residing outside of the window surrounding the funding discontinuity. My study incorporates a much larger cash flow shock than Bakke and Whited (2012), avoids potential endogeneity problems from using pension funding status, and speaks more generally to the relation between cash flow and real economic activities.

Instead of utilizing the annual variation in mandatory pension contributions, I employ a change in the ERISA pension accounting rules as an exogenous shock to a firm's internal capital. In 2012, Congress faced a funding shortage for two unrelated spending bills on student loan subsidization and transportation funding. With deadlines approaching, Congress passed Moving Ahead for Progress in the $21^{\text {st }}$ Century ("MAP21 "), which temporarily changed the ERISA pension accounting rules to decrease mandatory pension contributions. By lowering the level of mandatory pension contributions (which are tax-deductible) Congress projects higher tax revenue to fund the bills. Practitioners forecast that mandatory pension contributions decrease by $\$ 190$ billion through 2015 due to the rule change (Society of Actuaries 2012).

This ERISA accounting rule change provides an ideal setting to investigate how internal capital availability affects investment. First, the legislation surprises shareholders. During the passage of the rule change, firms in the top quartile of pension 
underfunding earned abnormal returns of 5.6 percent on a stand-alone basis and 2.8 percent more than firms in the lower three quartiles of pension underfunding. Second, the development of the pension rule change is arguably exogenous. Pension funding relief originates as a side effect of Congressional revenue shortages. Third, the change in pension funding obligations is economically significant. Data obtained from the Pension Benefit Guarantee Corporation ("PBGC") suggest that ERISA-based pension plan underfunding decreases by 80.6 percent and mandatory contributions decrease by 60.4 percent on average in 2012. Finally, there is significant cross-sectional variation in how the rule change affected firms' internal capital. Since mandatory pension contributions are a function of pension plan underfunding, the internal capital shock from the rule change covaries with the firm's pension funding position.

First, I investigate whether there is an effect from the internal capital shock from pension funding relief on investment for the average firm. I find evidence that capital expenditures increase, depending on my proxy for pension funding relief, and no average effect on research and development or cash acquisitions. The mixed evidence on investment suggests that managers may employ funds freed up for pension contributions for alternative purposes, in particular for payout policy and financial policy (i.e., cash holdings). I find strong evidence that managers employ pension relief from MAP-21 for share repurchases. Through 2013, practitioners expected the reduction in mandatory pension contributions to approximate $\$ 110$ billion. Of the $\$ 110$ billion, managers spent 14.7 percent to 21.3 percent on stock repurchases. 
In addition, I find that recipients of pension funding relief hold more cash after the accounting rule change. This effect is more prevalent for financially constrained firms and firms with the highest cash flow uncertainty. Firms retain approximately $34.1 \%$ to $51.7 \%$ of the pension funding relief as liquid assets on their balance sheet. Although there is a mixed effect of pension funding relief on firm investment, my findings on cash holdings suggest that pension funding relief provides managers flexibility to deploy internal capital for future financing needs.

The inconsistent relation between pension funding relief and investment suggests that there may be an investment effect from MAP-21, but this effect varies crosssectionally among the recipients of pension funding relief. For example, firms that have financing constraints or growth options are more likely to have immediate funding needs. In addition, the shock from pension funding relief is temporary and the timing of the reversal of the pension funding rules is uncertain. I also examine whether managers invest pension funding relief when a firm's secondary market for real assets is more active. I find that firms with higher growth options increase research and development expenses, consistent with MAP-21 supplementing immediate cash needs. Also, when a secondary market for real assets is more active, firms can more easily disinvest (Guiso and Parigi 1999). For industries in which asset reversibility is higher, I find firms are more likely to increase investment. Such firms can better adapt their investment policy given the uncertainty in future pension accounting rules.

Finally, as a robustness check, I reconduct my analysis using two separate pension regulatory shocks, the Pension Funding Equity Act of 2004 and the Pension Protection 
Act of 2006. The regulatory changes decreased and increased required mandatory pension contributions, respectively. I find that managers increase (decrease) shareholder payouts when mandatory pension contributions decrease (increase). This is consistent with managers paying out cash to shareholders when internal capital availability increases. In contrast, I find mixed evidence on the relation between investment and pension funding relief for the eight quarters following each regulatory change.

I contribute to the literature in the following ways. This study speaks to the unintended consequences of budgeting policy and the effectiveness of government incentives on managerial behavior. I find evidence that stock repurchases increase, a finding opposite of the legislation's intent and lobbyists' claims. However, some firms alter their investment policy after MAP-21. Investment increases in industries with active secondary markets and for firms with high growth options. The effectiveness of the current act has implications on future ERISA pension accounting rules. The Senate recently approved extending the lower interest rates from MAP-21 through 2020, but this bill has not cleared the House (Buck Consultants 2014). In addition, I add to the growing literature that studies the effects of financial frictions on real economic activity by exploiting a pension accounting rule change as an exogenous shock to firms' internal capital. Early studies that find exogenous internal capital shocks influence investment utilize small samples and are difficult to generalize (e.g., Blanchard et al., 1994, Lamont 1997, and Bates 2005). Using a much larger capital shock and an arguably exogenous setting, my evidence suggests a temporary cash flow change can effect managers' real economic decisions. 


\section{Literature Review}

In a frictionless market, the costs of internal capital and external capital are equivalent and the sole determinant of investment is investment opportunities. Managers are indifferent between utilizing internal or external funds, thus a firm's internal capital availability does not influence its investment choices (Modigliani and Miller, 1958). However, in a market with informational asymmetry between managers and investors, internal capital and external capital are not perfect substitutes (e.g., Jensen and Meckling, 1976, Myers and Majluf, 1984). With informational imperfections, investors demand a risk premium, and firms seeking external funds for investment suffer from adverse selection (Akerlof 1970). Thus, when managers face higher costs of outside financing, they depend on internal capital for investment financing needs.

To capture the relation between internal capital and investment in the presence of financing frictions, researchers have used cash flow to proxy for internal capital. In an influential paper, Fazzari et al. (1988) provide empirical evidence that investment varies with cash flow, rather than solely the availability of investment opportunities. This association between investment and internal capital is strongest when firms are financially constrained. Numerous papers reconfirm and build on this result (see Stein 2003 for a comprehensive literature review). However, researchers have challenged the interpretation and robustness of investment-cash flow sensitivity. Using their classification of financial constraints, Kaplan and Zingales $(1997,2000)$ find that the least financially constrained firms have a positive association between investment and cash flow. Researchers also attribute investment cash flow sensitivity to measurement 
error in investment opportunities (Erickson and Whited, 2000) or cash flow (Bushman et al., 2012). Erickson and Whited (2000) argue that correcting for measurement error in investment opportunities leads to less biased estimates of the effect of cash flow on investment, and the two variables are no longer related. Bushman et al. (2012) decompose the typical cash flow measure in the literature, earnings before depreciation, into GAAP operating cash flow and working capital accruals. They find a positive association between capital expenditures and working capital accruals, since both investment decisions relate to firm growth, but find no relation or a negative relation between capital expenditures and GAAP operating cash flow. Chen and Chen (2012) find that investment-cash flow sensitivity has declined rapidly over the past two decades.

To cleanly identify the relation between investment and cash flow, an ideal method exploits a shock to cash flow that is uncorrelated with investment opportunities. ${ }^{1}$ For example, litigation awards, oil price shocks, and asset sales have been employed as cash flow shocks (Blanchard et al. 1994, Lamont 1997, and Bates 2005, respectively). These studies find an association between internal capital and investment, but suffer from small samples and are difficult to generalize.

Rauh (2006) and Bakke and Whited (2012) use pension funding rules to investigate how investment covaries with exogenous changes in cash flow. This setting provides some exogenous variation in cash flow since stock market returns affect pension

\footnotetext{
${ }^{1}$ Along with shocks to internal capital, researchers have also investigated supply-side shocks to external capital availability. For example, using the recent financial crisis as a supply side shock, Balakrishnan et al. (2013) argue that firms with less conservative accounting have larger information frictions with lenders. They find firms with less conservative accounting endure a sharper decline in investment versus firms with more conservative accounting.
} 
plan assets and market interest rates affect both pension assets and the present value of pension liabilities. In the sample period from these two papers, if a pension plan is above a certain funding threshold (ERISA pension assets/ERISA pension liabilities) no pension contributions are required. These papers use the kink in pension funding rules to identify a causal effect of internal capital on investment. Rauh (2006) finds that investment decreases as mandatory pension contributions increase. He utilizes the entire distribution of firms with defined benefit plans. Bakke and Whited (2012) argue that researchers cannot purge pension funding status of its correlation with unobservable investment opportunities, except for observations immediately around the funding thresholds. Mandatory pension contributions jump up discretely at several different funding thresholds. Bakke and Whited (2012) find no evidence of a change in capital expenditures (but some evidence that employment and research and development increase) if firms achieve funding ratios that avoid mandatory pension contributions. Bakke and Whited (2012) caveat that their findings may not be generalizable for observations outside of their sample.

Informational imperfections that cause higher external capital costs not only allow investment to be more sensitive to internal capital availability; such imperfections can induce managers to retain more cash out of cash flows. Keynes (1936) notes the accessibility of external capital markets has a direct impact on the liquidity of firms' balance sheets. To the extent that managers anticipate future financing constraints or income uncertainty they can hoard cash for precautionary savings (Opler et al., 1999, 
Riddick and Whited, 2009). Almeida et al. (2004) find that financially constrained firms retain cash flow in their cash holdings, while unconstrained firms do not.

In a contemporaneous paper, Kubick et al. (2014) utilize the pension funding relief from MAP-21 in a similar manner as this paper. ${ }^{2}$ Our papers differ in several ways. First, Kubick et al. (2014) uses GAAP data instead of ERISA data. GAAP data (here, expected 2011 pension contributions) includes foreign pension commitments, which are not privy to pension relief from MAP-21, and it includes voluntary contributions, which the firm sets with discretion. Second, their regressions employ annual data instead of quarterly data. Since Congress passed MAP-21 in June 2012, it is difficult to classify 2012 observations as treated (e.g., post MAP-21). ${ }^{3}$ Finally, Kubick et al. (2014) study the effect of MAP-21 on capital investment whereas this paper examines payout policy and financial policy in addition to investment.

\section{Institutional Background}

\subsection{Setting}

I use an exogenous shock to pension funding requirements to identify the relation between investment and cash flows. In this section, I provide background on pension funding rules under ERISA and discuss how changes in ERISA pension accounting rules provide this identification. Companies with defined benefit plans promise employees a monthly payment upon retirement. The monthly payment is a function of the number of

\footnotetext{
${ }^{2}$ In particular, they find that R\&D increases in fiscal year 2012, capital expenditures decrease in fiscal year 2012, and capital expenditures increase in fiscal year 2013.

3 This affects roughly one-half of their post-MAP-21 sample.
} 
years of employment, the employees' salary at retirement, and cost of living adjustments. ERISA established the PBGC in 1974 to encourage the continuation and maintenance of private defined benefit pension plans by insuring future pension payments. ${ }^{4}$ If an employer demonstrates to the PBGC that it does not have enough capital to pay all benefits owed to the pension plan, then the PBGC takes over the plan and all its assets. ${ }^{5}$ The Department of Labor, through ERISA, monitors pension plan sponsors and requires mandatory contributions to such plans via an accounting formula. As funding status declines, firms are required to contribute more to their pension plans.

Most pension plans were fully funded (i.e., the value of pension assets is at least as large as the present value of pension liabilities) at the turn of the century. However, the recession in the early 2000s led to large equity losses and lower interest rates. This dramatically lowered pension funding and increased mandatory pension contributions. Figure 1 reports GAAP-based pension funding $\left(\frac{\text { GAAP pension assets }}{\text { GAAP pension liabilities }}\right)$ and employer pension contributions from 1999 through $2013 .{ }^{6}$ The average pension plan decreased from 117 percent funded in 1999 to 77.6 percent in $2002 .^{7}$ After the drop in funding

\footnotetext{
${ }^{4}$ The PBGC receives insurance premiums from defined benefit plan employers based on a fixed rate per employee and variable rate that increases as a function of plan underfunding. Currently, the PBGC guarantees up to $\$ 57,500$ per annum for employees who retire after 65 years of age.

${ }^{5}$ Only distressed terminations lead to PBGC transfers, which occur at the PBGC's discretion. However, numerous practitioners and researchers show that Congress underprices pension insurance premiums, leading to severe moral hazard problems (see, e.g. Love et al., 2011, Bereskin 2010).

${ }^{6}$ I report GAAP-based pension data here instead of ERISA-based pension data. GAAP pension accounting has not undergone any significant calculation changes since 1999 whereas ERISA pension accounting rules incurred significant revisions in 2008 and 2012. Thus, GAAP pension accounting provides more meaningful trend analysis.

${ }^{7}$ I utilize MAP-21 instead of the PPA for my regulatory shock for two reasons. First, the GAAP pension disclosure rules changed simultaneously with the change to ERISA pension accounting rules under the PPA. Second, there was a two-year lag from initiation of the PPA to the rules being effective whereas MAP-21 was immediately effective, making identification of the treatment period difficult. Nevertheless, I conduct a similar study using PPA as pension accounting rule change in Table 9.
} 
status in 2002, the PBGC took over large underfunded pension plans from several bankrupt companies. Pension plan participants and the federal government were concerned about the sustainability of the PBGC (Campbell et al., 2010).

To placate retirees' concerns regarding severe pension plan underfunding and to strengthen the fiscal viability of the PBGC, Congress approved the Pension Protection Act of 2006 (the "PPA"). The PPA shortens the window for pension plans to be fully funded from thirty years to seven years (Campbell et al., 2010) and institutes new plan administration restrictions and tax penalties when firms' pension funding falls below certain thresholds. Pension contributions increase once the PPA rules come into effect.

\subsection{Pension Funding Rules under the Pension Protection Act}

Each year, pension plan sponsors must contribute a minimum amount to their pension plans ("mandatory contributions" or " $M C s$ "). MCs consist of two components: an estimate of future pension benefits earned that year (discounted by ERISA interest rates) and the Shortfall Contribution. The Funding Shortfall is the difference between ERISA pension liabilities and ERISA pension assets, net of historical funding prepayments. The annual Shortfall Contribution is approximately equivalent to the payment term of an annuity to pay down the Funding Shortfall in seven equal installments. I provide the detailed Shortfall Contribution formula in Appendix A.

Pension obligations due within five years, due between five and twenty years, and due after twenty years are discounted to present value by segments one, two, and three, respectively, of the modified yield curve. The interest rate for each of the three segments is based on investment grade bond yields (AAA, AA, and A) with comparable maturities 
(see Figure 2 for an example). Thus, mandatory contributions are a function of both the segment rates and the level of pension plan underfunding (ERISA pension liabilities ERISA pension assets).

\subsection{Legislative History and Pension Funding Rules under MAP-21}

Firms have lobbied for pension funding relief since the PPA went into effect. Firms claim that the Treasury's monetary policy keeps market interest rates artificially low, thus inflating ERISA pension liabilities and mandatory contributions (Bradford 2012). In Figure 1, total pension contributions by firms with defined benefit plans increased by 48 percent from $\$ 78.4$ billion in 2008 to $\$ 115.8$ billion in 2009 , the first full year when contributions are calculated under PPA rules (contributions are inflation adjusted to 1999). The increased volatility of pension contributions also put additional strain on plan sponsors, which led to more pension plan terminations (Munnell and Soto, 2007).

Echoing this sentiment, the American Benefits Council states that "the sevenyear amortization created unmanageable obligations following the 2008 downturn... funding requirements in the near term will be far greater than necessary to meet longterm pension obligations, creating significant economic inefficiencies and forcing employers to divert important resources to fulfill an artificial obligation." Pension funding relief came about as Congress faced a June 30, 2012 deadline on two unrelated spending bills: a bill to improve the country's transportation infrastructure and a bill to extend student loan interest subsidies. Congress could not agree on how to fund these projects. Democratic Sen. Baucus proposed increasing estate tax rates whereas a 
majority of Republicans desired a reduction in President Obama's healthcare plan or lower federal pension commitments to governmental employees. During a February 2012 Congressional subcommittee meeting, the CFO of U.S. Steel indicated that the company planned to spend $\$ 1$ billion on new facilities, creating thousands of jobs to stimulate the economy, but this investment "could take a backseat to our pension funding demands in a low interest rate environment" (Bradford 2012). When estate taxation increases could not gather consensus in the Senate (see Appendix B), senators considered ERISA pension accounting reform as a potential solution to their revenue shortages. Pension funding relief allows firms to contribute less to their pension plans. Since pension contributions are tax deductible, Congress expects corporate tax receipts to increase. ${ }^{8}$

After contentious negotiations, Congress changed the ERISA pension accounting rules to fund the transportation and student loan bills. Under Moving Ahead for Progress in the $21^{\text {st }}$ Century ("MAP-21"), effective July 6, 2012, the ERISA discount rate smoothing window increases from a 2-year average to a 25 -year average of investment grade bond yields. Figure 2 displays the ERISA discount rates before and after MAP-21. After MAP-21, discount rates increased by 179.8 percent for pension liabilities due within 5 years, 35.1 percent for pension liabilities due between 5 and 20 years, and 21.5 percent for pension liabilities due after 20 years (rates are as of January 1, 2012). The interest rate change causes a large decrease in mandatory contributions.

\footnotetext{
${ }^{8}$ The increase in tax revenues from MAP-21 ultimately depends on how plan sponsors employ the pension funding relief for alternative uses. Certain investments (such as R\&D) earn an immediate tax deduction whereas other financing activities have no corporate tax effect (e.g., stock repurchases) or can reduce other corporate tax shields (e.g., debt prepayments).
} 
Figure 3 displays the estimated annual mandatory contributions under the preMAP-21 and post-MAP-21 rules over the next decade from the Society of Actuaries (2012). The dark-colored bars project mandatory contributions under the pre-MAP-21 rules. The light-colored bars project mandatory contributions under the post-MAP-21 rules. MAP-21 decreases mandatory contributions by approximately 44 percent in 2012, 51 percent in 2013, 34 percent in 2014, and 8 percent in 2015. The change in ERISA pension accounting is expected to reduce mandatory contributions by $\$ 190$ billion through 2015 (Society of Actuaries 2012). In 2016 and beyond, expected mandatory contributions are higher under the MAP-21 regime. $^{9}$

The rule change extends beyond a pension contribution holiday. Comparing mandatory pension contributions under the pre-MAP-21 regime and the post-MAP-21 regime through 2023, inflation adjusted mandatory contributions are still $\$ 45$ billion lower under MAP-21. At MAP-21's passing, pension plan sponsors became aware that pension funding relief can be utilized as a revenue raiser, making future revisions to pension plan funding rules more palatable for Congress. Currently, a MAP-21 extension through 2020 is contained in the Emergency Unemployment Compensation Extension Act of 2014. The Senate passed the bill in April 2014 and the House has not brought it up for a vote (Buck Consultants 2014).

To inform pension plan stakeholders how MAP-21 effects plans on an individual basis, Congress required pension plans to provide funding updates to pension plan

\footnotetext{
${ }^{9}$ The pension relief awarded to plan sponsors declines over time. If the 25 -year average discount rate falls within 10 percent (15 percent) $\{20$ percent $\}$ [25 percent] $\{\{30$ percent $\}\}$ of the 2 -year average in 2012 (2013) $\{2014\}$ [2015] $\{\{2016$ and forward $\}\}$ then the plan sponsor must use the 2 -year average rate.
} 
participants, unions, and the PBGC. Figure 4 illustrates an example of the effect of MAP-21 on pension funding obligations for DuPont. Prior to the accounting rule change, DuPont has a Funding Shortfall of $\$ 4.1$ billion. With the MAP-21 discount rates, DuPont's Funding Shortfall decreases by $\$ 2.5$ billion to $\$ 1.6$ billion (61 percent decrease). Mandatory contributions in 2012 decrease from \$664 million to \$264 million (60 percent decrease). Thus, MAP-21 provides DuPont with $\$ 400$ million in pension funding relief in 2012 and reduces its pension-related cash flow obligations over the next several years. I obtain these funding notices from two sources: the PBGC via a Freedom of Information Act ("FOIA") request ${ }^{10}$ and from the Internet via a web search engine. For my sample of 330 annual funding notices, I find that Funding Shortfalls decrease by 83.3 percent and mandatory contributions in 2012 decrease by approximately 60.3 percent on average (untabulated). In sum, MAP-21 provides a large increase to firms' internal capital via pension funding relief. To examine how the internal capital shock influences firms' real economic activities, I first describe the data and my empirical proxies for pension funding relief.

\section{Data and Research Design}

\subsection{Data Description}

The Department of Labor tabulates ERISA pension plan data from the tax Form 5500 on its website (www.dol.gov). I match the Department of Labor pension plan data

\footnotetext{
${ }^{10}$ Firms are not required to provide funding notices to the PBGC unless their Funding Shortfalls are greater than $\$ 50$ million. Per investigation of the sample from the FOIA request the submission of funding notices to the PBGC does not appear to be strictly enforced and the sample is incomplete.
} 
to Compustat by employer identification number (EIN); however, this matching is incomplete. Compustat lists one EIN whereas each taxpaying division of a firm has an EIN. For non-direct EIN matches, I hand match the pension plan sponsor from the Form 5500 to Compustat using Hoovers, SEC.gov, or Google for all plans with pension assets above $\$ 10$ million. I aggregate ERISA pension liabilities and ERISA pension assets by firm. I collect GAAP financial statement information from Compustat and stock market information from CRSP. After matching the ERISA pension plan data to Compustat, I am able to identify 2,655 plans from 1,356 unique firms.

I require firms to be either incorporated or headquartered in the United States. I remove firms that are in the regulated industries (e.g., banks, utilities), transportation, construction, and courier services, ${ }^{11}$ and firms that have stock prices below $\$ 1$. I include firms without ERISA pension plans to incorporate non-treated observations in my analysis. Given the concern identified in Bakke and Whited (2012) that outliers drive the results in Rauh (2006), all continuous variables are winsorized at the top and bottom 2.5 percent. The investment and financing regressions include 33,949 quarterly observations from January 1, 2011 to December 31, 2013 (+/- six quarters from initiation of MAP-21). The stock return analysis includes 2,560 observations.

\subsection{Identification Strategy}

MAP-21 causes a large, unexpected change in near-term pension funding obligations. The ideal empirical proxy to measure the effect of the regulatory shock is the change in pension underfunding or mandatory contributions directly attributable to

\footnotetext{
11 These industries generate non-pension related benefits from MAP-21's passage.
} 
MAP-21 (see Figure 4 for an example). Unfortunately, firms are not required to publicly disclose their annual funding notices. Thus, I consider four proxies to approximate the pension funding relief from MAP-21: the level of pension underfunding, the level of mandatory contributions, the pension funding ratio $\left(\frac{\text { ERISA pension assets-funding prepayments }}{\text { ERISA pension liabilities }}\right)$, and an indicator variable equal to 1 when a pension plan has a pension funding ratio below 80 percent. $^{12}$ I measure these proxies prior to the MAP-21 rule change. In Appendix C, I regress changes in mandatory contributions or pension underfunding due to MAP-21 (from my FOIA sample) on my empirical proxies for pension relief. I find that pension underfunding and mandatory contributions are positively associated with the pension funding relief disclosed on the MAP-21 annual funding notices. ${ }^{13}$ I utilize both pension underfunding and mandatory contributions as empirical proxies for pension funding relief in the subsequent empirical analysis.

I do not consider GAAP-based pension measures. GAAP employs a different accounting system than ERISA, GAAP has no direct effect on pension related cash flows, and GAAP includes foreign pension obligations that are not privy to the pension funding relief from MAP-21.

\footnotetext{
12 The PPA requires additional pension contributions, restricts lump sum payouts, and restricts executive compensation corporate tax deductibility if a plan's funding target ratio is below 80 percent.

${ }^{13}$ For pension underfunding, I do not include funding prepayments in the calculation. These can increase mandatory pension contributions. However, since pension plan managers can set funding prepayments to zero I do not consider these relevant in determining firms' economic pension liabilities.
} 


\subsection{MAP-21 Event Study}

I conduct an event study to determine when shareholders react to the pension accounting rule change. This serves two purposes. First, it determines whether pension funding relief is unanticipated. Second, it identifies the timing of pension funding relief treatment. I hand collect the dates of the legislative events of MAP-21. I search press releases from major news outlets on Factiva and Lexis-Nexis using keyword searches from January 2012 to the signing of the legislation by the President. ${ }^{14}$ Appendix B and Table 1 detail the key legislative dates. I calculate two-day abnormal stock returns ([0, $+1])$ for each legislative event as $R_{i t}-R_{E W R E T}$ where $R_{i t}$ equals return for firm $i$ on day $t$ and $R_{E W R E T}$ equals the CRSP equal weighted return on day $t .^{15}$

As discussed in Brown and Warner (1985), though short-term abnormal returns are generally well specified, when the event dates cluster around similar events, crosssectional correlation tends to underestimate the standard errors. Following Campbell and Wasley (1993), I create portfolios and calculate the standard deviation using time series data from the average portfolio return to control for cross-correlation. ${ }^{16}$ I create three different portfolios corresponding to pension existence and funding status. If a firm's aggregate pension underfunding (ERISA pension liabilities - ERISA pension assets), as a

\footnotetext{
${ }^{14}$ My search procedure was "pension" AND ("transportation" OR "MAP-21") AND (“Congress" OR "House" OR "Senate").

${ }^{15}$ If the first press release of the key date occurred after 5:00 pm, I utilize the following day to measure the abnormal returns.

16 The portfolio test statistic is $\sum_{t=1}^{T} \bar{u}_{t} / \sqrt{\sum_{t=1}^{T}\left((1 / 119) \sum_{n=1}^{120}\left(\bar{u}_{n}-\overline{\bar{u}}\right)^{2}\right)}$, where $\bar{u}_{t}$ is the average portfolio abnormal return, $R_{i t}-R_{E W R E T}$, from day $\mathrm{t}, \overline{\bar{u}}$ is the average of the average daily portfolio returns around the event window.
} 
percentage of the firm's total assets, ${ }^{17}$ ("Underfund") is in the upper quartile of the sample of firms with ERISA-based pension plans, I assign the observation to the high Underfund ("Hi UF") portfolio. Firms with no ERISA-based pension plans are in the no pension ("No P") portfolio. I assign the remaining firms to the low Underfund ("Lo UF") portfolio.

Table 1, Panel A provides a description of the key legislative events and the portfolio abnormal stock returns. Four (Two) of the legislative event windows have statistically significant abnormal stock returns for the Hi (Lo) UF sample. The signs of the returns are consistent with pension funding relief benefitting shareholders since the largest stock market reactions occur for Hi UF firms. Congressional approval of the pension funding relief bill generated the largest stock market reaction. No individual events are statistically significant in the No P portfolio. The Lo UF portfolio generates abnormal stock returns of 2.6 percent $(t-s t a t=2.11)$ over the seven events. The Hi UF portfolio generates abnormal stock returns of 5.6 percent $(\mathrm{t}$-stat $=2.75)$ over the seven events. Buying the Hi UF portfolio and selling the Lo UF [No P] portfolio generates abnormal stock returns of 3.3 percent $(t-s t a t=2.28)[2.9$ percent $(t-s t a t=2.30)]$ over the seven events. To summarize, I find pension funding relief surprised the market, is value enhancing to shareholders, and the largest abnormal return occurs when Congress approves the bill (June 29, 2012).

\footnotetext{
${ }^{17}$ Scaling pension underfunding using pension plan specific data, such as pension plan assets, or identifying high pension underfunding firms by their funding target ratios, is not informative of how economically significant the underfunding liability is to the firm's operations.
} 
To determine whether financially constrained firms benefit the most from MAP21, I partition the Hi UF abnormal returns by the firms' Standard and Poor's credit rating to determine if external capital costs influence the shareholder reaction to MAP-21. In Table 1, Panel B, I partition the Hi UF portfolio into firms without credit ratings, below investment grade firms, and investment grade firms. I find that cumulative abnormal returns are the highest for Hi UF firms with either no credit rating $(\mathrm{CAR}=5.2$ percent, $\mathrm{t}$ statistic $=2.51)$ or a below-investment grade credit rating $(\mathrm{CAR}=7.4$ percent, $\mathrm{t}$-statistic $=2.30$ ). Aggregate abnormal stock returns for the investment grade Hi UF portfolio are statistically insignificant. This is consistent with Campbell et al. (2010), who find that during the passage of the PPA (which increased mandatory contributions) firms with the lowest credit ratings earn more negative abnormal returns. Hence, shareholders of the most financially constrained firms generate the largest benefit from MAP-21.

Pension funding relief can be value enhancing to shareholders in several ways. In line with the results from Table 1 Panel B, financially constrained firms can invest the cash from pension funding relief in projects that were unattainable due to high external costs of capital. To the extent that no profitable projects are immediately available, shareholders can still benefit from firms holding the pension funding relief as cash for liquidity purposes or by distributing pension relief funds to shareholders and creditors. MAP-21 reduces pension-related cash flow uncertainty. Given that cash flow volatility is a key determinant of payout policy (Chay and Suh, 2009); shareholders may anticipate increased equity payouts. To the extent that the demand curve for a firm's stock is downward sloping, managers can buy out shareholders with the lowest reservation prices 
via stock repurchases (Comment and Jarrell, 1991, Hodrick 1999). Increasing debt repayments via pension funding relief can reduce firm distress and lower the likelihood of debt covenant violations. To the extent that a firm is financially distressed, MAP-21 can potentially generate a wealth transfer from pension participants and the Federal government to the firms' shareholders and creditors. To evaluate these potential explanations of the market reaction to MAP-21, I next examine how managers deploy the pension funding relief from MAP-21.

\subsection{Empirical Design of Investment and Payout Policy Regressions}

To investigate how managers react to the internal capital shock from the change in pension accounting rules, I employ the empirical design of Dharmapala et al. (2011).

$$
\begin{aligned}
& \text { Investment or Payout Policy }_{i t}=\beta_{0}+\beta_{1} \text { Post }_{i t}+\beta_{2} \text { Funding Relief }_{i t}+ \\
& \beta_{3} \text { Post }_{i t} \times \text { Funding Relief } f_{i t}+\beta_{4} O C F_{i, t-1}+\beta_{5} \text { Cash }_{i, t-1}+\beta_{6} \text { Size }_{i, t-1}+ \\
& \beta_{7} \text { MTB }_{i, t-1}+\beta_{8} \text { Leverage }_{i, t-1}+\varphi_{q}+\varepsilon_{i t}
\end{aligned}
$$

where the dependent variable is the ratio of investment $\left(C A P X, R \& D,{ }^{18}\right.$ and Cash Acquisitions) or payout policy (Stock Repurchases, Dividends, and Debt Reduction) to lagged total assets. ${ }^{19}$ Post is an indicator variable equal to 1 when the firm-quarter observation is subsequent to the passage of MAP-21 (July 6, 2012) and is equal to 0

\footnotetext{
${ }^{18}$ When research and development is missing in Compustat the firm-quarter observation is set to zero. Retaining only the firm-quarter observations with non-zero amounts for research and development leads to similar results.

${ }^{19}$ Results in Tables 4 and 5 are robust to excluding No P observations and using alternative Underfund scalars (e.g. market capitalization).
} 
otherwise. ${ }^{20}$ I use two different variables to proxy for Funding Relief, the level of ERISA-based pension underfunding (Underfund) or ERISA mandatory contributions scaled by lagged total assets $(M C) .{ }^{21}$ To the extent that firms have overfunded pension plans or lack ERISA-based pension plans, I set Underfund and $M C$ equal to zero. Pension obligations have been shown both theoretically (Cooper and Ross, 2001) and empirically (e.g., Franzoni 2009, Campbell et al., 2010, 2012, Rauh 2006) to proxy for financing constraints which inhibit investment. If the pre-MAP-21 pension accounting rules distort optimal investment, then I expect investment to increase with pension funding relief, and thus expect a positive coefficient on Post $\times$ Funding Relief. Along with the internal capital shock from pension funding relief, I include two traditional measures of internal capital. Following Bushman et al. (2012), OCF is the GAAP-based operating cash flow scaled by lagged assets. Cash is the cash and short-term investments of the firm scaled by lagged assets. I include cash holdings considering the prior evidence that cash holdings affect corporate investment (e.g., Dharmapala et al., 2011, Harford 1999). Size is the natural log of the firm's market value of equity. MTB is the market-to-book ratio, calculated as (total assets - stockholders' equity + market value of equity)/ book value of total assets. I expect investment to be an increasing function of investment opportunities. Leverage is the ratio of long-term debt plus long-term debt in

\footnotetext{
${ }^{20}$ My results are robust to dropping the quarters immediately preceding and following the passage of MAP21 for the investment and equity payout policy regressions. The coefficient on $\beta_{3}$ becomes statistically insignificant for Debt Reduction.

${ }^{21}$ For the numerators of Underfund and $M C$, I use data from the 2011 Form 5500. This is the most recent Form 5500 information available prior to MAP-21 passing. Since most underfunded firms are required to make quarterly contributions from April $15^{\text {th }}$ of the current year to January $15^{\text {th }}$ of the following year, the 2011 underfunded amount is likely unaffected by the 2012 rule change.
} 
current liabilities scaled by the book value of assets. Prior empirical literature finds that investment is a decreasing function of leverage (e.g., Lang et al., 1996).

Congress' implemented MAP-21 to increase federal tax receipts and stimulate firm investment. To investigate the effectiveness of MAP-21 from Congress' perspective I investigate how MAP-21 influence other cash outflows, including payout policy. Consistent with Dharmapala et al. (2011), I employ a similar model to predict both investment and payout policy. ${ }^{22}$ To the extent that managers treat internal funds previously reserved for pension contributions as free cash flow, then I expect a positive coefficient on Post $\times$ Funding Relief. The remaining empirical predictions are consistent with prior literature. I predict that higher cash availability (measured by $O C F$ and $C a s h$ ) is positively associated with shareholder and creditor distributions. Creditors of highly levered firms are likely to restrict equity payouts, thus I expect that equity distributions are decreasing in leverage. I predict that debt payments increase for firms with more leverage. I expect firms with higher growth options to have lower equity distributions and debt reductions, all else equal. I lag the control variables for the investment and payout policy regressions by one quarter and include firm fixed effects to absorb unobserved heterogeneity. ${ }^{23}$

My panel contains six quarters of data in the pre-MAP-21 regime and the postMAP-21 regime. Since the accounting change occurs in the middle of 2012, I am limited in time series data for the MAP-21 regime. If there is a relation between an exogenous

\footnotetext{
${ }^{22}$ Alternative empirical specifications on the determinants of payout policy decisions (e.g. Blouin and Krull, 2009) provide quantitatively similar results.

${ }^{23}$ The main results are qualitatively similar excluding firm fixed effects.
} 
internal capital shocks (proxied for by pension funding relief) and investment, then I should be able to capture it in my analysis. Given that managers conduct capital budgeting annually, I presume six quarters provides managers enough time to incorporate the change in pension accounting rules in their capital budgeting program. In addition, anecdotal evidence suggests that managers delayed existing investment projects before the pension accounting rule change due to significant cash requirements for pension contributions (Bradford 2012, Rauh 2006).

Nevertheless, it is possible that my post-MAP-21 window is too short to pick up investment effects. If managers anticipate future financing needs, they may retain the cash from pension funding relief as liquid assets. I employ a deterministic model of cash and short-term investments from Opler et al. (1999, Table 4 Panel A).

$$
\begin{aligned}
& \text { Cash }_{i t}=\beta_{0}+\beta_{1} \text { Post }_{i t}+\beta_{2} \text { Funding Relief }_{i t}+\beta_{3} \text { Post }_{i t} \times \text { Funding Relief }_{i t} \\
& +\beta_{4} \text { MTB }_{i, t-1}+\beta_{5} \text { Size }_{i, t-1}+\beta_{6} \text { OCF }_{i, t-1}+\beta_{7} \text { Working Capital }_{i, t-1}+ \\
& \beta_{8} R \& D_{i, t-1}+\varphi_{q}+\varepsilon_{i t}
\end{aligned}
$$

where Cash, Post, Funding Relief, MTB, Size, $O C F$, and $R \& D$ are defined previously and in Appendix D. If firms retain pension funding relief from MAP-21, then the interaction of Post and Funding Relief should be positive and statistically significant. I expect firms with more investment opportunities, as proxied for by $M T B$, to hold more cash for future investment. $O C F$ captures the direct effect that cash flow has on the level of cash holdings. Working Capital is current assets, net of cash, less current liabilities scaled by 
total assets. Due to the liquidity of working capital, firms trade-off between working capital and cash holdings (Opler et al., 1999). I include firm fixed effects and control for the lagged level of research and development.

\subsection{Empirical Design of Cross-sectional Analyses}

The specifications detailed in the previous section estimate the effect of an internal capital shock from pension funding relief on an average firm's real economic activities. However, I expect these effects to vary based on firm characteristics. Namely, I construct tests to examine how a firm's financing constraints, investment opportunity set, and the redeployability of its assets influence such firm's response to MAP-21.

Theory suggests that internal capital becomes more valuable to firms with financing needs as external capital becomes more costly (Kaplan and Zingales, 1997), or as income uncertainty increases (Riddick and Whited, 2009). The MAP-21 event study in Section 4.2 reinforces this theory. Hi UF firms without a credit rating or with below investment grade debt earn the highest abnormal stock returns. I model how financing constraints affect the utilization of funds from pension relief for investment, payout policy, and cash retention as follows:

$$
\begin{aligned}
& \text { Investment }_{i t} \text { or Payout Policy }_{i t}=\beta_{0}+\beta_{1} \text { Post }_{i t}+\beta_{2} \text { Underfund }_{i t}+ \\
& \beta_{3} \text { Post }_{i t} \times \text { Underfund }_{i t}+\beta_{4} F C_{i, t-1}+\beta_{5} \text { Post }_{i t} \times F C_{i, t-1}+ \\
& \beta_{6} \text { Underfund }_{i t} \times F C_{i, t-1}+\beta_{7} \text { Post }_{i t} \times \text { Underfund }_{i t} \times F C_{i, t-1}+\beta_{8} \text { OCF }_{i, t-1} \\
& +\beta_{9} \text { Cash }_{i, t-1}+\beta_{10} \text { Size }_{i, t-1}+\beta_{11} \text { Leverage }_{i, t-1}+\beta_{12} \text { MTB }_{i, t-1}+\varphi_{i}+\varepsilon_{i t} \text { (3) } \\
& \text { Cash }_{i t}=\beta_{0}+\beta_{1} \text { Post }_{i t}+\beta_{2} \text { Underfund }_{i t}+\beta_{3} \text { Post }_{i t} \times \text { Underfund }_{i t}+ \\
& \beta_{4} \text { CC }_{i, t-1}+\beta_{5} \text { Post }_{i t} \times F C_{i, t-1}+\beta_{6} \text { Underfund }_{i t} \times F C_{i, t-1}+ \\
& \beta_{7} \text { Post }_{i, t-1} \times \text { Underfund }_{i t} \times F C_{i, t-1}+\beta_{8} \text { MT }_{i, t-1}+\beta_{9} \text { Size }_{i, t-1} \\
& +\beta_{10} \text { OCF }_{i, t-1}+\beta_{11} \text { Working Capital }_{i, t-1}+\beta_{12} R \& D_{i, t-1}+\varphi_{i} \\
& +\varepsilon_{i t .} .
\end{aligned}
$$


I use two common proxies in the literature for financing constraints $(F C)$, industry cash flow volatility (Opler et al., 1999) and the existence of a credit rating (Erickson and Whited, 2000, Almeida et al., 2004). Industry Sigma captures the riskiness of a firm's future cash flows. Industry Sigma Rank is the quartile rank of the two-digit industry standard deviation of operating cash flow scaled by lagged assets, and is equal to zero otherwise. ${ }^{24}$ This is a common empirical proxy for cash retention in the corporate finance literature (see Opler et al., 1999). No Credit Rating is an indicator variable equal to 1 when an observation does not have an $\mathrm{S} \& \mathrm{P}$ credit rating, and is equal to zero otherwise. The existence of a credit rating captures the market's assessment of the firm's credit quality (Almeida et al., 2004). I define the remaining variables from equations (3) and (4) earlier in this section and in Appendix D.

I expect a positive coefficient on Post $\times$ Underfund $\times F C$ for the investment regressions if pension funding relief alleviates contemporaneous financing needs. I expect a positive coefficient on Post $\times$ Underfund $\times F C$ for the cash holdings regression if managers retain pension funding relief for future financing needs. The effect of financing constraints on payout policy is ambiguous. Distributing free cash flow in unconstrained firms to residual claimants lowers the monitoring costs for shareholders (see Jensen 1986, Grullon and Michaely, 2004). This would suggest a positive coefficient on Post $\times$ Underfund and a negative coefficient on Post $\times$ Underfund $\times$

\footnotetext{
${ }^{24}$ Note that I used quartile ranks $(0,1,2$, and 3$)$ instead of continuous variables in all of my cross-sectional analyses herein. When continuous variables do not contain observations at zero (such as MTB or ISIGMA) then it is impossible to interpret the base variable effects.
} 
$F C$. To the extent that managers may try to extract wealth from retirees, payouts should increase for the most financially distressed firms. This scenario suggests a positive coefficient on Post $\times$ Underfund $\times F C$.

In my main empirical specification (e.g., model (1)), I measure the effect of the pension funding relief on investment and payout policy holding constant investment opportunities constant as an independent variable. However, I expect investment and payout policy decisions to vary cross-sectionally given firms' investment opportunity sets. Thus, I interact my proxy for growth opportunities, $M T B$, with pension funding relief and the post dummy to investigate further the relation between investment and cash flow shocks. I employ the following specifications:

$$
\begin{aligned}
& \text { Investment }_{i t} \text { or Payout Policy } \text { Pit }=\beta_{0}+\beta_{1} \text { Post }_{i t}+\beta_{2} \text { Underfund }_{i t}+ \\
& \beta_{3} \text { Post }_{i t} \times \text { Underfund }_{i t}+\beta_{4} \text { MTBRank }_{i, t-1}+\beta_{5} \text { Post }_{i t} \times \text { MTBRank }_{i, t-1}+ \\
& \beta_{6} \text { Underfund }_{i t} \times \text { MTBRank }_{i, t-1}+ \\
& \beta_{7} \text { Post }_{i t} \times \text { Underfund }_{i t} \times \text { MTBRank }_{i, t-1}+\beta_{8} O C F_{i, t-1}+\beta_{9} \text { Cash }_{i, t-1} \\
& +\beta_{10} \text { Size }_{i, t-1}+\beta_{11} \text { Leverage }_{i, t-1}+\varphi_{i}+\varepsilon_{i t} \text {. } \\
& \text { Cash }_{i t}=\beta_{0}+\beta_{1} \text { Post }_{i t}+\beta_{2} \text { Underfund }_{i t}+\beta_{3} \text { Post }_{i t} \times \text { Underfund }_{i t}+ \\
& \beta_{4} \text { MTBRank }_{i, t-1}+\beta_{5} \text { Post }_{i t} \times \text { MTBRank }_{i, t-1}+ \\
& \beta_{6} \text { Underfund }_{i t} \times \text { MTBRank }_{i, t-1}+ \\
& \beta_{7} \text { Post }_{i, t-1} \times \text { Underfund }_{i t} \times \text { MTBRank }_{i, t-1}+\beta_{8} \text { Size }_{i, t-1}+\beta_{9} O C F_{i, t-1} \\
& +\beta_{10} \text { Working Capital }_{i, t-1}+\beta_{12} R \& D_{i, t-1}+\varphi_{i}+\varepsilon_{i t}
\end{aligned}
$$

where, MTBRank is the quartile-based rank of MTB by year. I expect more investment from the cash flow shock when a firm has more investment opportunities, thus I expect a positive coefficient for $\beta_{7}$ for the investment-related and cash-holdingrelated managerial decisions and a negative coefficient on payout policy decisions. 
Industry characteristics also influence how firms respond to the pension funding relief from MAP-21. The discussion in Section 3.2 details how MAP-21, in its current form, is a temporary rule change. There is uncertainty as to how long firms will benefit from lower mandatory pension contributions. This may deter firms from employing the temporary pension funding relief towards long-term investment projects. Uncertainty can depress investment. This uncertainty is exacerbated when investment is irreversible (Guiso and Parigi 1999). Firms with more liquid secondary markets can more easily reverse their investment decisions if pension funding policy becomes more restrictive in the future. I follow Schonberger (2013) and proxy for asset liquidity with the frequency of industry acquisitions. I employ the following model:

$$
\begin{aligned}
& \text { Investment }_{i t} \text { or Payout Policy }{ }_{i t}=\beta_{0}+\beta_{1} \text { Post }_{i t}+\beta_{2} \text { Underfund }_{i t}+ \\
& \beta_{3} \text { Post }_{i t} \times \text { Underfund }_{i t}+\beta_{4} \text { M\&ARank } \text { Rat }-1+\beta_{5} \text { Post }_{i t} \times \text { M\&ARank }_{i, t-1}+ \\
& \beta_{6} \text { Underfund }_{i t} \times M \& A \text { Rank }_{i, t-1}+ \\
& \beta_{7} \text { Post }_{i t} \times \text { Underfund }_{i t} \times \text { M\&ARank } i, t-1+\beta_{8} O C F_{i, t-1}+ \\
& \beta_{9} \text { Cash }_{i, t-1}+\beta_{10} \text { Size }_{i, t-1}+\beta_{11} \text { Leverage }_{i, t-1}+\beta_{12} \text { MTB }_{i, t-1}+\varphi_{i}+\varepsilon_{i t} \text {. } \\
& \text { Cash }_{i t}=\beta_{0}+\beta_{1} \text { Post }_{i t}+\beta_{2} \text { Underfund }_{i t}+\beta_{3} \text { Post }_{i t} \times \text { Underfund }_{i t}+ \\
& \beta_{4} M \& \text { ARank }_{i, t-1}+\beta_{5} \text { Post }_{i t} \times M \& \text { ARank }_{i, t-1}+ \\
& \beta_{6} \text { Underfund }_{i t} \times M \& A \text { Rank }_{i, t-1}+ \\
& \beta_{7} \text { Post }_{i, t-1} \times \text { Underfund }_{i t} \times M \& \text { ARank }_{i, t-1}+\beta_{8} \text { MTB }_{i, t-1}+\beta_{9} \text { Size }_{i, t-1}
\end{aligned}
$$

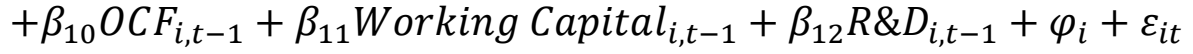

The measure for liquidity in secondary markets, M\&ARank, captures the quartile rank of the three year average of number of acquisitions by industry from SDC. I expect more investment when secondary markets for real assets are more active, thus a positive coefficient on $\beta_{7}$ for the investment-related and cash-holding-related managerial decisions. 


\section{Descriptive Statistics}

Table 2 presents descriptive statistics for the complete sample (Panel A) and for the No P, Lo UF, and Hi UF subsamples (Panel B). Again, Hi UF firms reside in the highest quartile of ERISA pension underfunding, Lo UF firms reside in the lower three quartiles of ERISA pension underfunding, and No P firms do not have ERISA-based defined benefit plans. ${ }^{25}$ For all firms, Underfund represents 0.3 percent of total assets. My empirical design constitutes the six quarters surrounding MAP-21, so 49 percent of my observations occur after the accounting rule change. The average firm in my sample has a market value of equity of $\$ 540.6$ million and book leverage of 19.4 percent (book value of debt scaled by lagged assets).

Average Underfund is equal to 0.4 (4.1) percent of total assets for the Lo (Hi) UF sample. ${ }^{26}$ Only 6.2 percent of firms have fully funded pension plans under the pre-MAP21 ERISA pension accounting rules (untabulated). For the Hi UF sample, average (median) ERISA pension underfunding covers 43.1 (65.12) percent of the average (median) cash balance and 16 (19.2) percent of the average (median) long-term debt outstanding. Quarterly pension contributions (from Compustat) for the Hi UF sample approximate 40.9 (18.9) percent of pretax income on average (at the median).

Comparing column [3] to column [1] of Panel B, Hi UF firms make fewer investments in terms of capital expenditures and research \& development. Hi UF firms are less likely to

\footnotetext{
${ }^{25}$ Replicating Table 3 using terciles or quintiles provides similar results.

${ }^{26}$ ERISA based underfunding is 8.3 (27.6) percent of ERISA pension assets.
} 
repurchase stock than Lo UF firms and No P firms on average. Hi UF firms hold less cash and have more leverage than No P firms. Due to their higher leverage, Hi UF firms have larger debt cash outflows.

\section{Empirical Results}

6.0. Univariate Analysis

Before conducting the multivariate analysis, Table 3 reports the average levels in investment and payout policy before and after MAP-21. Panel A, column [C] reports the average change in investment and payout policy after MAP-21, grouped by pension existence and pension funding status. I find no evidence of a change in $C A P X$ for the three subgroups after MAP-21. Research and development increases for No P firms. Both the No P (diff. $=-0.0004$, t-stat $=3.14)$ and Low UF firms decrease stock repurchases $($ diff. $=-0.006$, t-stat $=2.18)$ in the MAP-21 regime. High UF firms increase stock repurchases by 0.1 percent of total assets per quarter in the MAP- 21 regime $(\mathrm{t}$-stat $=$ 3.05), or a 40.8 percent increase. Figure 5 provides evidence that the increase in stock repurchases and the decrease in pension contributions for Hi UF firms occurs in the first full quarter following MAP-21 (e.g., firms with quarters ending between October 1, 2012 and December 31, 2012). The one-quarter delayed response is consistent with implementation guidance not being available from the PBGC or the IRS until the middle of September 2012. ${ }^{27}$ There is no obvious trend in capital expenditures subsequent to

\footnotetext{
${ }^{27}$ Pension plan shortfall contributions are due on April $15^{\text {th }}$, July $15^{\text {th }}$, October $15^{\text {th }}$ of the current plan year, and January $15^{\text {th }}$ of the following plan year. President Obama approved MAP-21 on July 6, 2012. Figure 6 reports the July contribution in " $\mathrm{Q}+1$ " and the October contribution in " $\mathrm{Q}+2$ ".
} 
MAP-21, except for calendar year fourth quarter observations being higher than the calendar year non-fourth quarter observations (Shin and Kim 2002).

Table 3, Panel B reports the difference in differences estimates between the three subgroups. The difference-in-difference specification here and in Section 6.1 allows me to identify relative differences in investment and payout policy between firms that benefit from the internal capital shock from pension funding relief and firms that do not.

Repurchases increase for Hi UF firms relative to the No P firms (diff-in-diff $=0.002, \mathrm{t}=$ 3.91) and the Lo UF firms (difference-in-difference $=0.002, \mathrm{t}=3.75$ ). Comparing the $\mathrm{Hi}$ UF firms to the No P firms dividends decrease (diff-in-diff $=-0.0004$, t-stat $=2.14$ ), but this relation does not hold in the multivariate analysis or when comparing Hi UF firms to Lo UF firms. I find no evidence of a relative change in debt reductions, at least in the univariate analysis. To the extent that heterogeneity influences my results, I include firm fixed effects in my multivariate analysis.

\subsection{Multivariate Results}

I present results from with Underfund as my proxy for pension relief in Table 4. Columns [1] through [3] report results with investment-related dependent variables whereas columns [4] through [6] report results with payout policy-related dependent variables. In Table 4, I find no evidence that pension funding relief results in an increase in research and development, or cash acquisitions. The coefficients on Post $\times$ Underfund are statistically insignificant in columns [2] and [3]. However, I do find evidence of an association between capital expenditures and pension funding relief in the MAP-21 regime. This is consistent with pension obligations being a binding constraint 
on investment. The control variables are generally consistent with the prior literature. For each dollar of pension underfunding, stock repurchases increase by $\$ 0.022$ in each quarter of the MAP-21 regime. Total ERISA underfunding pre-MAP-21 was \$112 billion. ${ }^{28}$ This equates to a $\$ 14.8$ billion increase in capital expenditures $(112 \times 0.022 \times 6$ quarters), or approximately 13.4 percent of total pension funding relief through $2013 .{ }^{29}$

Next, I examine how MAP-21 affects managers' payout policies. Stock repurchases are positively associated with pension funding relief (coefficient $=0.024, \mathrm{p}$ value $=0.006$ ). For each dollar of pension underfunding, stock repurchases increase by $\$ 0.024$ in each quarter of the MAP-21 regime. This equates to a $\$ 16.1$ billion increase in stock repurchases $(112 \times 0.024 \times 6$ quarters $)$, or approximately 14.7 percent of total pension funding relief through 2013. I find no evidence that dividends vary with pension underfunding subsequent to MAP-21. This is consistent with managers choosing repurchases over dividends when their firms receive transient cash flow shocks (Guay and Harford, 2000). I also find that debt payments increase as a function of pension funding relief in the MAP-21 regime $($ coeff. $=0.07, \mathrm{p}$-value $=0.091)$. For each dollar of pension underfunding, debt payments increase by $\$ 0.071$ in each quarter of the MAP-21 regime. This equates to $\$ 47.7$ billion in debt payments $(112 \times 0.071 \times 6$ quarters $)$, or approximately 43.4 percent of pension funding relief through 2013.

\footnotetext{
${ }^{28}$ This is the total underfunding from all Form 5500s filed in 2011 matched to Compustat.

${ }^{29}$ From Figure 3, the change in mandatory pension contributions due to MAP-21 is \$110 billion in 2012 and 2013 combined. Thus, capital expenditures represented 13.4 percent (14.6/110) of pension funding relief.
} 
I use an alternative pension funding relief measure in Table 5, the level of mandatory contributions $(M C)$ prior to the accounting rule change. Using $M C$ to proxy for pension funding relief, I find no evidence that capital expenditures, research and development, or cash acquisitions increase for the recipients of pension funding relief in the six quarters subsequent to MAP-21. Similar to the results in Table 5, pension funding relief measured by $M C$, leads to an increase in stock repurchases (coeff. $=0.063$, p-value $=0.005)$. Using this alternative measure, stock repurchases represent approximately $\$ 23.4$ billion of the $\$ 110$ billion decrease in mandatory contributions through 2013 . The coefficient on $M C$ is statistically insignificant for the dependent variables Debt Reduction and Dividends. Consistent with the prior literature, Cash and $O C F$ are positively associated with equity payouts, Leverage reduces equity payouts, and higher growth options make stock repurchases less likely.

The results in Tables 4 and 5 suggest that pension funding relief and the contemporaneous reduction in pension-related cash flow uncertainty induce recipients to increase shareholder payouts. I find some evidence that creditor payouts and capital expenditures increase, but only for one pension funding relief proxy and only in the multivariate analyses. ${ }^{30}$

The mixed evidence between investment and pension funding relief may result from a lack of contemporaneous investment projects for the treated firms. As an alternative to immediate investment, managers can retain funds from MAP-21 as liquid

\footnotetext{
${ }^{30}$ Results are qualitatively similar if a Tobit is utilized for equations (1) and (2) instead of ordinary least squares, with the exception of the coefficient of Post $\times$ Underfund becoming statistically insignificant for the debt reduction regression.
} 
assets if they anticipate future financing constraints and future investment funding needs. I investigate the effect of pension funding relief on a firm's cash holdings. Table 6 displays the results from equation (2). I report results where Underfund (column [1]) and $M C$ (column [2]) approximate pension funding relief. Both coefficients on Post $\times$ Underfund (coeff. $=0.340$, p-value $<0.001)$ and Post $\times M C$ (coeff. $=0.924$, p-value $<$ 0.001) are positive and statistically significant. This implies that recipients of pension relief retain funds as cash and short-term investments on their balance sheets. For each dollar of pension underfunding, cash and short-term investments increase by $\$ 0.340$ in the MAP-21 regime. This comprises $34.6 \%$ percent of total pension funding relief through $2013\left(\frac{0.34 \times 112,000}{110,000}\right)$. The control variables from equation (2) are generally in line with the prior literature (see Opler et al., 1999). ${ }^{31}$ As a robustness check, I investigate and find that employing working capital instead of cash and cash equivalents as the dependent variable provides similar results.

\subsection{Cross-sectional Results}

To summarize my results above, I find strong evidence that firms respond to the rule change by increasing shareholder payouts (14.7 percent to 21.3 percent of pension funding relief) and retaining additional cash on their balance sheet to alleviate future financing needs (34.6 percent to 51.7 percent of pension funding relief). I also find some evidence that capital expenditures and debt payouts increase, but only for one of my two empirical proxies for pension funding relief. In this section, I conduct several cross-

\footnotetext{
31 The relation between cash holdings and growth options is statistically insignificant in my empirical specification. When removing firm fixed effects $M T B$ becomes statistically significant (coeff. $=0.018$, pvalue $<0.001)$.
} 
sectional analyses to exploit the heterogeneity in firms' financing needs and potential financing constraints.

I first investigate the role of financing constraints on the relation between the cash flow shock from pension funding relief and firm investment and payout policy decisions. In Table 7, I interact my proxy for pension funding relief with measures of financing constraints $(F C)$ and Post. Columns [1] and [2] approximate financing constraints with the existence of a credit rating and columns [3] and [4] approximate financing constraints with industry cash flow volatility (income uncertainty). I find no evidence that more financially constrained firms employ pension funding relief for contemporaneous investment or payout policy. In fact, I find that firms with higher cash flow volatility are less likely to use pension funding relief for cash acquisitions (coeff. $=0.032$, $\mathrm{p}$-value $=$ 0.013). However, I do find evidence that firms without credit ratings (coeff. $=0.335, \mathrm{p}$ value $=0.017)$ and firms with higher cash flow uncertainty $($ coeff. $=0.231, \mathrm{p}$-value $=$ 0.004) are more likely to retain funds from pension funding relief as liquid assets than firms with S\&P credit ratings and firms with lower cash flow risk, respectively. This is suggestive of financially constrained pension funding relief recipients holding the funds as liquid assets for future financing needs. The ability of financially constrained firms to hold more cash from pension funding relief on the balance sheet also corroborates my evidence that firms with financing constraints earned the highest abnormal returns during MAP-21's passage.

In addition, I expect firms with unfulfilled investment opportunities to be the most likely to immediately increase investment. Columns [1] and [2] of Table 8 interact firms' 
investment opportunity sets, MTB, with Post $\times$ Underfund. I find that firms in the highest quartile of $M T B$ are more likely to increase $R \& D$ (coeff. $=0.021$, $\mathrm{p}$-value $=$ 0.035). The coefficients on Post $\times$ Underfund $\times$ MTBRank are negative for the payout policy regressions and positive for the cash holdings regressions, but not statistically significant. This is consistent with firms' immediately utilizing funding relief from MAP-21 to increase investment.

Finally, I investigate how a firm's secondary market for real assets affects its utilization of pension funding relief. MAP-21, as currently constructed, temporarily lowers pension contributions. Managers may be wary to overinvest if the regulatory environment is uncertain and firms are not able to disinvest. Based on the results in Table 8, columns [3] and [4] the utilization of pension funding relief for capital expenditures only occurs in industries in which secondary market activity is more frequent. I proxy for secondary market activity by using a measure from Schonberger (2013), M\&ARank. ${ }^{32}$ I find that firms with more active secondary markets are more likely to utilize pension funding relief for capital expenditures $($ coeff. $=0.018$, p-value $=$ 0.053 ) and hold the pension funding relief as cash (coeff. $=0.182, \mathrm{p}$-value $=0.007$ ). These investment decisions appear to come at the expense of using the pension funding relief to pay down debt, which is less likely for firms that operate in more active secondary markets (coeff. $=-0.086, \mathrm{p}$-value $=0.043)$.

\footnotetext{
${ }^{32}$ I incorporate this measure as a proxy for secondary market activity since SDC acquisitions include private firms as well as public firms whereas Compustat-based asset sales are restricted to public firms only.
} 
In summary, I find that the utilization of the cash flow shock from pension funding relief is contingent upon a firm's particular financing needs and investment opportunities. Pension plan sponsors with higher investment opportunities utilize the pension funding relief to increase $R \& D$, whereas financially constrained firms tend to retain the pension funding relief as cash to alleviate future financing needs. Given the fact that MAP-21 funding relief is temporary, firms are more likely to invest when they can more easily reverse investment. Although the dominant utilization of MAP-21 pension funding relief is attributed to stock repurchases and cash retention, I find some support that MAP-21 influences certain firms' investment policy effectively, by freeing up cash for immediate investment needs.

\subsection{Robustness Test}

I utilize MAP-21 as an exogenous shock to a firm's internal capital given the magnitude of shock itself, its plausibly exogenous origin, and the short-time period in which MAP-21 is legislated and effective. However within the two years surrounding MAP-21, several large economic shocks occurred, such as the implementation of the Dodd-Frank Act and the bank instability and bank bailouts in Europe, which could potentially speak to my mixed findings of capital investment. The difference-indifference specification helps alleviate these concerns, such that an alternative shock (other than pension relief) that causes my results must only affect those firms that receive pension relief at the exact time when MAP-21 becomes effective. Nevertheless, as a robustness check, I attempt to replicate my previous results using alternative legislative 
shocks to the ERISA pension accounting rules that occur before the implementation of MAP-21.

Two other noteworthy ERISA pension accounting changes occurred in the past decade, the Pension Funding Equity Relief Act (PFE) and the PPA. Similar to MAP-21, the PFE changes the interest rate to discount ERISA pension liabilities to present value. The PFE increases the discount rate from a 30-year treasury yield to a four-year weighted average of corporate bond yields, signed in April 2004 and effective for the two plan years beginning after January 1, 2004. The PPA, signed on August 17, 2006, reduces the discount rate to a two year average corporate bond yield and requires an expedited pension contribution schedule (see Section 3.1 for more details) effective January 1, 2008. Plan sponsors must fully fund their pension plan in seven years versus thirty years in the pre-PPA regime (Campbell et al. 2010). The rule changes differ in that the PFE provides pension-funding relief whereas the PPA forces plan sponsors to contribute more to their pension plans. ${ }^{33}$ I utilize my previous empirical design with eight quarters surrounding each alternative pension accounting rule change.

$$
\begin{aligned}
& \text { Investment or Payout Policy }_{i t}=\beta_{0}+\beta_{1} \text { PostPFE }_{i t}+\beta_{2} \text { Funding Relief }_{i t} \\
& +\beta_{3} \text { PostPFE }_{i t} \times \text { Funding Relief }_{i t}+\beta_{4} \text { OCF }_{i, t-1}+\beta_{5} \text { Cash }_{i, t-1}+ \\
& \beta_{6} \text { Size }_{i, t-1}+\beta_{7} \text { MTB }_{i, t-1}+\beta_{8} \text { Leverage }_{i, t-1}+\varphi_{q}+\varepsilon_{i t},
\end{aligned}
$$

Investment or Payout Policy $y_{i t}=\beta_{0}+\beta_{1}$ PostPPA $_{i t}+\beta_{2}$ Funding Relief $_{i t}$

\footnotetext{
${ }^{33}$ Unlike MAP-21, the PPA rule change is not immediately effective. The new rules do not take effect until January 1, 2008. In addition, the PPA is legislated over a much longer time-period. These issues can lead to potential look-ahead bias and the results herein should be interpreted with caution.
} 


$$
\begin{aligned}
& +\beta_{3} \text { PostPPA }_{i t} \times \text { Funding Relief }_{i t}+\beta_{4} \text { OCF }_{i, t-1}+\beta_{5} \text { Cash }_{i, t-1}+ \\
& \beta_{6} \text { Size }_{i, t-1}+\beta_{7} \text { MTB }_{i, t-1}+\beta_{8} \text { Leverage }_{i, t-1}+\varphi_{q}+\varepsilon_{i t}
\end{aligned}
$$

In this specification PostPFE (PostPPA) is an indicator variable equal to 1 if the firm-quarter observation occurs after April 12, 2004 (December 31, 2007). Funding Relief is the GAAP-based level of pension underfunding (GAAP pension liabilities minus GAAP pension assets scaled by lagged quarterly assets) in the year prior to the ERISA pension accounting rules changes. For the purposes of this analysis, I consider GAAP data inferior to ERISA data (see Section 4.1). However, ERISA pension accounting data is not available from the DOL database in a machine-readable format in 2008 and I did not hand-match the ERISA EINs to Compustat for the prior two pension accounting regimes. The definitions of the remaining variables are consistent with the previous section and tabularized in Appendix D. Table 9 reports the results for the alternative pension rule changes.

The first column in Table 9 reports the coefficients with PFE as the regulatory shock. The PFE increased the interest rate to discount pension liabilities to present value, thus lowering mandatory contributions. I find that managers react to the internal capital shock from pension relief by increasing stock repurchases (coeff. $=0.006, \mathrm{p}$-value $=$ 0.004), but no evidence that capital investment changes in the post-PFE regime.

Next, I examine how the PPA influences firms' real economic activities. The PPA originated because pensionholders and Congress were concerned with the financial 
viability of the PBGC (Campbell et al. 2010). The expedited repayment schedule provided a more rapid pension contribution schedule for pension plan sponsors. If internal capital shocks deter investment, then I expect investment to decrease in the postPPA regime. I find mixed evidence of this in column [2] of Table 9. Research and development decreases with the increased pension contribution requirements (coeff. = 0.018, p-value 0.001). However, capital expenditures actually increase after MAP-21 (coeff. $=0.034, \mathrm{p}$-value $<0.001)$. In terms of payout policy, managers respond to the internal capital decrease by reducing payouts in terms of dividends (coeff. $=-0.003$, $\mathrm{p}$ value $=0.005)$ and stock repurchases $($ coeff. $=-0.012, p$-value $=0.018)$. The cumulative evidence suggests that internal capital shocks affect managers' payout policy, but the average firm's investment decisions appear dependent on things other than pensionfunding changes legislated by Congress.

These robustness tests should be interpreted cautiously for several reasons. First, other legislative changes occurred simultaneously with the PPA. In addition to the PPA, Congress increased Section 179 tax deductions and special depreciation deductions to induce capital investment. This incentivizes firms to increase capital investment and may deter firms from alternative funding strategies. Again, since I employ a difference-indifference specification the effect of the additional tax deductions must be concentrated in firms that have higher pension underfunding. Secondly, I use GAAP-based data for these tests, which increases the measurement error in my empirical proxies for pension funding relief. Finally, the PPA (and the PFE to a lesser extent) is legislated over a 
longer time period, thus identifying the timing of treatment in an empirical setting becomes more difficult.

\section{Conclusion}

The previous literature produces mixed results on whether legislation intended to spur investment is ultimately effective (Blouin and Krull, 2009, Dharmapala et al., 2011, Faulkender and Petersen, 2012). This paper employs a recent change in ERISA pension accounting rules that provides pension-funding relief for firms with significant pension underfunding as an exogenous shock to internal capital availability. The internal capital shock is arguably exogenous since Congress granted the pension funding relief in a lastminute effort to pass two unrelated bills. I find mixed evidence that the cash flows from the reduction of mandatory contributions under MAP-21 have an immediate effect on investment. I find that the utilization of the cash flow shock from pension funding relief is contingent upon a firm's particular financing needs and investment opportunities. Pension plan sponsors with higher investment opportunities utilize the pension funding relief to increase $R \& D$, whereas financially constrained firms tend to retain the pension funding relief as cash to alleviate future financing needs. Given the fact that MAP-21 funding relief is temporary, firms are more likely to invest when they can more easily reverse investment.

Moreover, I find strong evidence that the change in pension accounting rules leads to an increase in stock repurchases. These results hold in various specifications and are robust to considering alternative pension regulations changes prior to MAP-21. Stock repurchases comprise 14.7 percent to 21.3 percent of the pension funding relief granted 
by MAP-21. The results herein have implications to the extent Congress decides to extend the pension relief from MAP-21 through 2020. 


\section{References}

Akerlof, G. A. 1970. The market for "lemons": Quality uncertainty and the market mechanism. Quarterly Journal of Economics 84: 488-500.

Almeida, H., Campello, M., and Weisbach, M.S. 2004. The cash flow sensitivity of cash. Journal of Finance 59: 1777-1804.

Bakke, T., and Whited, T. 2012. Threshold events and identification: a study of cash shortfalls. Journal of Finance 67: $1083-1111$.

Balakrishnan, K., Watts, R., and Zuo, L. 2013. Accounting conservatism and firm value: Evidence from the global financial crisis. MIT Working Paper.

Bates, T.W. 2005. Asset sales, investment opportunities, and the use of proceeds. Journal of Finance 60: 105-135.

Bereksin, FL. 2010. Determinants of defined benefit plan pension policies. University of Rochester Working Paper.

Blanchard, O., Lopez-de-Silanes, F., Shleifer, A. 1994. What do firms do with cash windfalls? Journal of Financial Economics 36: 337-360.

Blouin, J., and Krull, L. 2009. Bringing it home: a study of the incentives surrounding the repatriation of foreign earnings under the American Jobs Creation Act of 2004. Journal of Accounting Research 47: 1027 - 1059.

Bradford, H. 2012. Corporate pension plans ready to seek more relief. Pensions \& Investments: February 22, 2012.

Brown, S., and Warner, J. 1985. Using daily stock returns: The case of event studies. Journal of Financial Economics 14: 3 - 31.

Buck Consultants, LLC. 2014. Uncertain future for MAP-21 extension; expatriate plan fix for ACA and gender pay disparity legislation fail to advance. Legislate: 5: 1.

Bushman, R.M., Smith, A.J, Zhang, X.F. 2012. Investment cash flow sensitivities really reflect related investment decisions. University of North Carolina at Chapel Hill Working Paper

Campbell, C., and Wasley, C.W. 1993. Measuring security price performance using daily NASDAQ returns. Journal of Financial Economics 33: 73 - 92. 
Campbell, J.B, Dhaliwal, D., and Schwartz, W. 2010. Equity valuation effects of the pension protection act of 2006. Contemporary Accounting Research 27: $469-$ 536.

Campbell, J.B., Dhaliwal, D., and Schwartz, W. 2012. Financing constraints and the cost of capital: Evidence from the funding of corporate pension plans. Review of Financial Studies 25: 868-912.

Chay, J.B., and Suh, J. 2009. Payout policy and cash-flow uncertainty. Journal of Financial Economics 93: 88-107.

Chen, H.J., and Chen, S.J. 2012. Investment-cash flow sensitivity cannot be a good measure of financial constraints: Evidence from the time series. Journal of Financial Economics 103: 393-410.

Comment, R., and Jarrell, G.A. 1991. The relative signaling power of Dutch-auction and fixed-price self-tender offers and open-market share repurchases. Journal of Finance 46: 1243-1271.

Cooper, R.W., and Ross, T.W. 2001. Pensions: theories of underfunding. Labour Economics 8: 667-689.

Create jobs, increase investment, strengthen pensions, and raise revenue by stabilizing the pension funding interest rate rules. The American Benefits Council. May 15, 2012.

Dharmapala, D., Foley, F., and Forbes, K. 2011. Watch what I do, not what I say: the unintended consequences of the Homeland Investment Act. Journal of Finance 66: $753-787$.

Erickson, T., and Whited, T. 2000. Measurement error and the relationship between investment and q. Journal of Political Economy 108: 1027-1057.

Faulkender, M., and Petersen, M. 2012. Investment and capital constraints: repatriations under the American Jobs Creation Act. Review of Financial Studies 25: 3351 3388.

Fazzari, S., Hubbard, G.H., and Petersen, B. 1988. Financing constraints and corporate investment. Brookings Papers on Economic Activity.

Franzoni, F. 2009. Underinvestment vs. overinvestment: Evidence from price reactions to pension contributions. Journal of Financial Economics 92: $491-518$. 
Grullon, G., and Michaely, R. 2004. The information content of share repurchase programs. Journal of Finance 59: 651-680.

Guay, W. and Harford, J. 2000. The cash-flow permanence and information content of dividend increases versus repurchases. Journal of Financial Economics 57: $385-415$.

Guiso, L., and Parigi, G. 1999. Investment and demand uncertainty. Quarterly Journal of Economics 114: 185-227.

Harford, J. 1999. Corporate cash reserves and acquisitions. Journal of Finance 54: 1969-1997.

Hodrick, L.S. 1999. Does stock price elasticity affect corporate financial decisions?. Journal of Financial Economics 52: 225-256.

Jensen, M.C., and Meckling, W.H. 1976. Theory of the firm: managerial behavior, agency costs and ownership structure. Journal of Financial Economics 3: 305360 .

Jensen, M.C. 1986. The agency costs of free cash flow, corporate finance, and takeovers. The American Economic Review 76: 323-329.

Kaplan, S.N., and Zingales, L. 1997. Do investment-cash flow sensitivities provide useful measures of financial constraints. Quarterly Journal of Economics 112: $169-215$.

Kaplan, S.N., and Zingales, L. 2000. Investment-cash flow sensitivities are not valid measures of financing constraints. Quarterly Journal of Economics 115: 707712 .

Kubick, T.R., Lockhart, G.B., and Robinson, J.R. 2014. Internal Capital and Investment: Evidence from 2012 Pension Relief. University of Texas at Austin Working Paper.

Keynes, J. 1936. The general theory of employment, interest, and money (McMillan, London).

Lamont, O. 1997. Cash flow and investment: evidence from internal capital markets. Journal of Finance 52: 83-109.

Lang, L., Ofek, E., and Stulz, R. 1996. Leverage, investment and firm growth. Journal of Financial Economics 40: 3 - 29. 
Love, D.A., Smith, P.A., and Wilcox, D.W. 2011. The effect of regulation on optimal corporate pension risk. Journal of Financial Economics 101: 18-35.

Modigliani, F., and Miller, M.H. 1958. The cost of capital, corporation finance and the theory of investment. The American Economic Review 48: 261-297.

Munnell, A., and Soto, M. 2007. Why are companies freezing their pension plans? Center for Retirement Research at Boston College Working Paper.

Myers, S.C., and Majluf, N.S. 1984. Corporate financing and investment decisions when firms have information that investors do not have. Journal of Financial Economics 13: 187-221.

Opler, T., Pinkowitz, L., Stulz, R., and Williamson, R. 1999. The determinants and implications of corporate cash holdings. Journal of Financial Economics 52: 346.

Postal, A. 2012. Stretch IRA provision removed from highway bill. LifeHealthPro.com: February 22, 2012.

Proposed pension funding stabilization: how does it affect the single-employer defined benefit system. Society of Actuaries. 2012.

Rauh, J. 2006. Investment and financing constraints: evidence from the funding of corporate pension plans. Journal of Finance 61: $33-71$.

Riddick, L.A., and Whited, T.M. 2009. The corporate propensity to save. Journal of Finance 64: 1729-1766.

Shin, H.H., and Kim, Y.H. 2002. Agency costs and efficiency of business capital investment: evidence from quarterly capital expenditures. Journal of Corporate Finance 8: 139-158.

Schonberger, B. 2013. Real asset liquidity and asset impairments. University of Southern California Working Paper.

Stein, J.C. 2003. Agency, information and corporate investment. Handbook of the Economics of Finance 1: 111-165. 


\section{Appendix A: Calculation of the Shortfall Contribution}

The ERISA pension funding rules require firms to contribute minimum amounts to their pension plans consisting of Shortfall Contributions and the future pension benefits earned (discounted to present value using ERISA interest rates). Shortfall Contributions are a function of Funding Shortfalls and ERISA interest rates. FS, the Funding Shortfall, is equal to ERISA pension liabilities less ERISA pension assets, net of funding prepayments. ERISA pension liabilities are discounted by the two (twenty-five) year average of investment grade bonds with maturities based on a modified yield curve pre (post)-MAP-21. ERISA pension liabilities and assets are determined on the first day of a plan year. The Shortfall Contribution is calculated as follows:

$$
\text { Shortfall Contribution }_{t}=\sum_{t=t-N \mid t \geq 2008}^{t \mid t \geq 2008} S A I_{t},
$$

where $S A I_{t}=\frac{S A B_{t}}{A F_{N, t}}$,

where $S A B_{t}=F S_{t}-P V S A B_{t}$.

The plan sponsor calculates a Shortfall Amortization Base (SAB) for each year. The Shortfall Amortization Base for year $t$ is equal to the Funding Shortfall (FS) in year $t$ less the present value of the uncontributed Shortfall Amortization Bases from prior years $(P V S A B)$. Plan sponsors contribute the Shortfall Amortization Base for year $t$ to the pension plan over seven equal installments starting with year $t$ to year $t+7$. The contribution for year $t$ 's $S A B$ is the Shortfall Amortization Installment (SAI), calculated as the $S A B$ for year $t$ by an Annuity Factor $\left(A F_{N, r_{t}}\right){ }^{34}$ The Shortfall Contribution for year $t$ is the sum of the Shortfall Amortization Installments for each $S A B$ tranche that has not yet been fully contributed. Once firms fully fund their pension plans, Shortfall Contributions are no longer required. Shortfall Contributions are due in quarterly installments on April

\footnotetext{
${ }^{34}$ Congress provided additional pension relief in 2010 when it allowed amortization of certain $F S$ over 15 years. However, electing this option restricted equity payouts to shareholders and executive compensation. Anecdotally, from inspection of the 2010 and 2011 Form 5500s from the Department of Labor, the election was infrequent.
} 
$15^{\text {th }}$, July $15^{\text {th }}$, and October $15^{\text {th }}$ of a given plan year and January $15^{\text {th }}$ of the following year. 


\section{Appendix B: Legislative History of MAP-21}

Congress introduced MAP-21 in November of 2011 to increase state funding for transportation projects. Legacy versions of MAP-21 included estate tax increases to pay for the bill, but the estate tax provisions did not garner bipartisan support in the Senate (Postal 2012). Aware of pension funding relief lobbying and the unpopularity of estate tax increases, Democrats changed the funding strategy for MAP-21 on February 15, 2012. Sen. Harry Reid removed the estate tax increases and replaced them with pension funding relief. The provision increased the discount rate smoothing window from 2 years to 10 years.

On March 12, 2012, Sen. Barbara Boxer amended MAP-21 to replace the 10-year smoothing window with a 25-year window. MAP-21 subsequently passed the Senate on March 14, 2012 with a bipartisan vote of 74 to 22. On March 21, 2012, the House introduced MAP-21 and then immediately shelved the bill. On April 16, 2012, the House of Representatives re-introduced MAP-21. House Democrats and Republicans struggled to compromise, and the House passed their version of MAP-21 without pension funding relief on April 19, 2012. 


\section{Appendix C: Validation of Funding Relief Proxies}

The annual funding notices (obtained from the Internet and the PBGC) report the pre- and post-MAP-21 mandatory contributions and Funding Shortfalls for 2012. The annual funding notices report the actual change in pension obligations from MAP-21, but these notices are not publicly available for all pension plans (see Figure 4 for an example). Therefore, I need to consider potential proxies to capture pension funding relief from MAP-21. I regress the change in mandatory contributions or the change in the Funding Shortfall from my sample of annual funding notices on four proxies for pension funding relief.

$$
\begin{aligned}
& \Delta \mathrm{MC}_{\mathrm{MAP}-21} \text { or } \Delta \text { Shortfall }_{\mathrm{MAP}-21}=\beta_{0}+\beta_{1} \mathrm{MC}_{2011}+\beta_{2} \text { Underfund }_{2011} \\
& +\beta_{3} \text { Pension Funding Ratio } \\
& 2011
\end{aligned}
$$

where $\triangle \mathrm{MC}_{\mathrm{MAP}-21}$ is the reduction in mandatory contributions from adopting MAP-21 in 2012. $\Delta$ Shortfall $_{\mathrm{MAP}-21}$ is the reduction in the Funding Shortfall from adopting MAP-21 in 2012. MC $_{2011}$ is the plan's latest mandatory contribution prior to the rule change. Underfund $\mathrm{d}_{2011}$ is the plan's latest pension underfunding (ERISA pension liabilities - ERISA pension assets) prior to the rule change. Since contribution requirements decline as the Funding Shortfall approaches zero, the level of pension underfunding and the level of mandatory contributions pre-MAP-21 should predict MAP21 pension funding relief from the annual funding notices.

Pension Funding Ratio 2011 is calculated prior to the rule change, equal to $\frac{\text { ERISA pension assets-funding prepayments }}{\text { ERISA pension liabilities }}$. ReliefD $\mathrm{D}_{2011}$ is an indicator variable equal to 1 if the pension plan has a pension funding ratio below 80 percent, and is equal to zero otherwise. An additional Shortfall Contribution is required if the pension funding ratio is below 80 percent and the pension plan meets certain conditions. I scale $\Delta \mathrm{MC}_{\mathrm{MAP}-21}$, $\Delta$ Shortfall $_{\mathrm{MAP}-21}, \mathrm{MC}_{2011}$, and Underfund ${ }_{2011}$ by the number of pension plan participants.35 If my explanatory variables appropriately capture the pension funding

\footnotetext{
35 Since nonpublic firms provide most of my annual funding notice sample, I cannot scale by total assets.
} 
relief from MAP-21, then I expect positive coefficients on $\mathrm{MC}_{2011}$, Underfund 2011 , and ReliefD $_{2011}$; and expect a negative coefficient on PensionFundingRatio ${ }_{2011}$. I report the coefficients from equation C.1 in Table C.

Table C

Pension Funding Relief Empirical Proxies

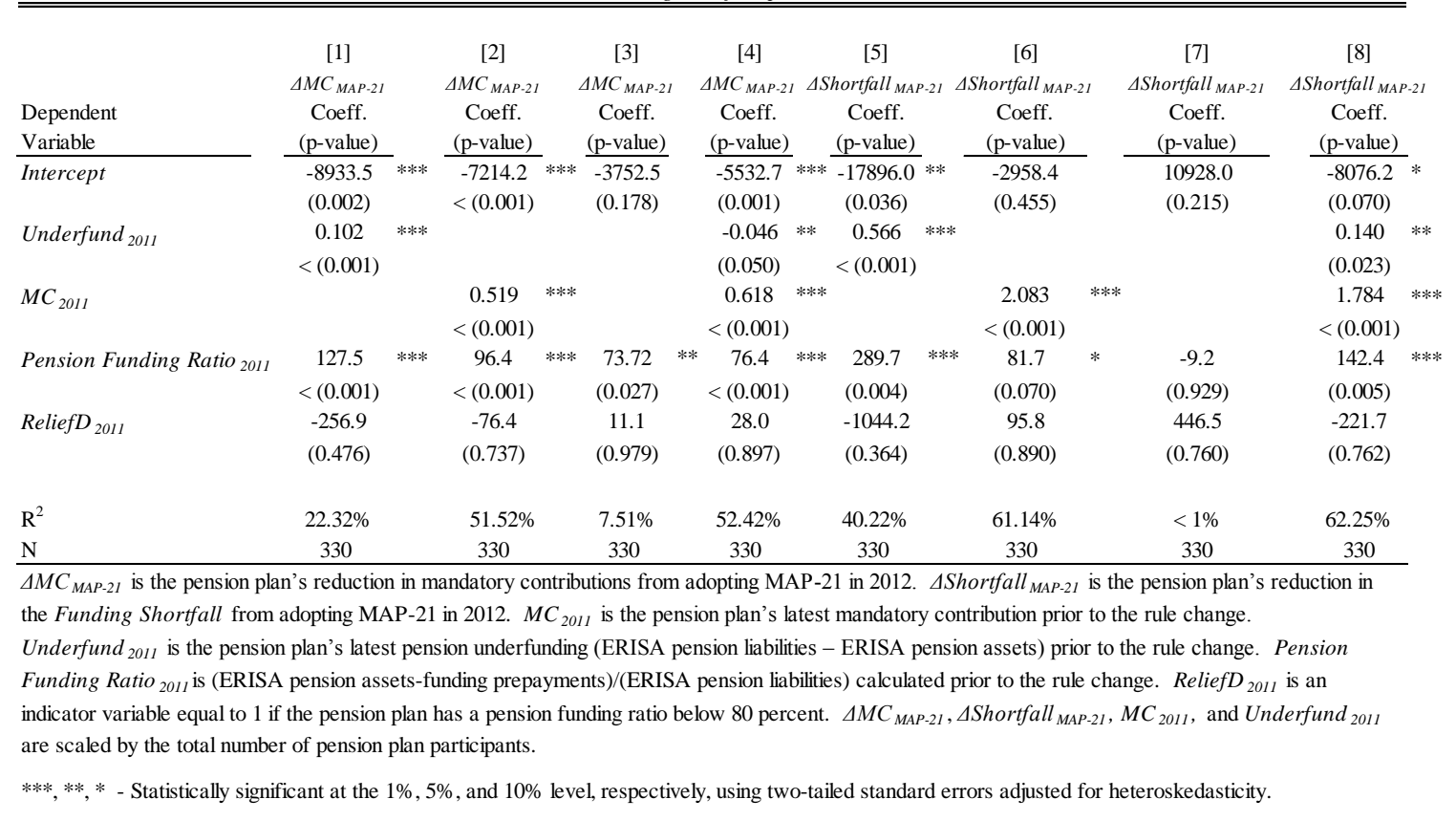

Columns (1) through (4) include results where the change in mandatory contributions due to MAP-21 is the dependent variable and columns (5) through (8) display results where the change in the Funding Shortfall due to MAP-21 is the dependent variable. Due to concerns of multicollinearity, I run models excluding Underfund2011 in columns (2), (3), (6) and (7) and excluding MC2011 in columns (1), (3), (5), and (7). Underfund2011 is a significant determinant of pension funding relief in columns (1), (5), and (8); but the coefficient changes signs in column (4), where MC2011 subsumes its explanatory power. There is no evidence that MAP-21 pension funding relief is associated with ReliefD2011. When Underfund2011 and MC2011 are excluded from regressions (3) and (7), there is a large decrease in explanatory power, as measured by the adjusted R2. The coefficient on Pension Funding Ratio2011 is either statistically 
insignificant or reports an opposite sign in each specification. MC2011 is a significant determinant in all specifications when it is included as an independent variable. For every \$1 of MC2011, mandatory contributions decrease by approximately \$0.52 in 2012 (column 2). For every $\$ 1$ of Underfund2011, firms' funding obligations decrease by $\$ 0.57$ after MAP-21 goes into effect (column 5). Based on the analysis above, I employ both the level of pension underfunding and mandatory contributions as empirical proxies for MAP-21 pension funding relief.

As a robustness check, I regress $\triangle \mathrm{MC}_{\mathrm{MAP}-21}$ and $\Delta \mathrm{Shortfall}_{\mathrm{MAP}-21}$ on Underfund2011, MC2011, the ERISA interest rate, and indicator variable for a frozen plan, and the natural

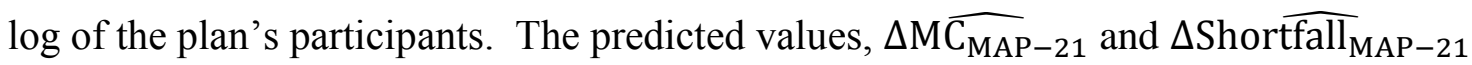
are used as alternative measures of pension relief in my main analysis. Results are qualitatively similar with the alternative specifications. 


\section{Appendix D: Variable Definitions}

\begin{tabular}{|c|c|}
\hline Variable & Description \\
\hline Underfund & $\begin{array}{l}\text { A continuous variable measuring the level of ERISA pension } \\
\text { underfunding Max(0,(ERISA pension liabilities - ERISA pension } \\
\text { assets)), measured prior to the rule change scaled by lagged } \\
\text { assets. }\end{array}$ \\
\hline$M C$ & $\begin{array}{l}\text { ERISA-based annual mandatory contributions, measured prior to } \\
\text { the rule change scaled by lagged assets. }\end{array}$ \\
\hline Pcont & $\begin{array}{l}\text { Quarterly cash pension contributions scaled by total assets (from } \\
\text { Compustat). }\end{array}$ \\
\hline Post & $\begin{array}{l}\text { An indicator variable equal to } 1(0) \text { when the quarter end date is } \\
\text { after (before) July } 6,2012 \text {. }\end{array}$ \\
\hline PostPFE & $\begin{array}{l}\text { An indicator variable equal to } 1(0) \text { when the quarter end date is } \\
\text { after (before) April 12, 2004. }\end{array}$ \\
\hline Post PPA & $\begin{array}{l}\text { An indicator variable equal to } 1(0) \text { when the quarter end data is } \\
\text { after (before) December } 31,2007 \text {. }\end{array}$ \\
\hline CAPX & Capital expenditures scaled by lagged assets. \\
\hline$R \& D$ & Researc \\
\hline Cash Acq. & Cash expenditures for acquisitions scaled by lagged assets. \\
\hline Dividends & Dividends scaled by lagged assets. \\
\hline Repurchases & Stock repurchases scaled by lagged assets. \\
\hline Debt Reduction & $\begin{array}{l}\text { Debt reduction from the statement of cash flows scaled by lagged } \\
\text { assets. }\end{array}$ \\
\hline$P T I$ & Pretax income scaled by lagged assets. \\
\hline$O C F$ & Cash flow fro \\
\hline Cash & Cash and short term investments scaled by lagged assets. \\
\hline Size & The natural $\log$ of the market value of equity. \\
\hline$M T B$ & $\begin{array}{l}\text { The market value of equity + book assets - stockholders' equity } \\
\text { scaled by lagged assets. }\end{array}$ \\
\hline MTBRank & The quartile rank $\{0 \ldots 3\}$ of $M T B$ by year. \\
\hline Leverage & The book value of long term debt scaled by lagged assets. \\
\hline Working Capital & $\begin{array}{l}\text { Current assets net of cash - current liabilities scaled by total } \\
\text { assets. }\end{array}$ \\
\hline Industry Sigma & $\begin{array}{l}\text { The standard deviation of operating cash flows scaled by lagged } \\
\text { assets by two-digit SIC industry by year (minimum of } 10 \\
\text { observations). }\end{array}$ \\
\hline SigmaRank & The quartile rank $\{0 \ldots 3\}$ of Industry Sigma by year. \\
\hline No Credit Rating & $\begin{array}{l}\text { An indicator variable equal to } 1 \text { when the firm does not have a } \\
\text { credit rating from S\&P (per Compustat), and is equal to zero } \\
\text { otherwise. }\end{array}$ \\
\hline Acquisition Count & $\begin{array}{l}\text { The three year average of the number of acquisitions in SDC by } \\
\text { two digit industry. }\end{array}$ \\
\hline
\end{tabular}




\begin{tabular}{|l|l|}
\hline Variable & Description \\
\hline M\&ARank & The quartile rank $\{0 \ldots 3\}$ of $M \& A$ Count by year. \\
\hline $\begin{array}{l}\text { Pension Funding } \\
\text { Ratio }\end{array}$ & Calculated as $\frac{\text { ERISA pension assets-funding prepayments }}{\text { ERISA pension liabilities }}$ \\
\hline ReliefD & $\begin{array}{l}\text { An indicator variable equal to } 1 \text { if the firm's Pension Funding } \\
\text { Ratio is less than } 80 \text { percent. }\end{array}$ \\
\hline Hi (Lo) UF & $\begin{array}{l}\text { The highest (lowest three) quartile(s) of Underfund for firms with } \\
\text { ERISA-based pension plans. }\end{array}$ \\
\hline
\end{tabular}




\section{Table 1: Abnormal Stock Returns from Pension Funding Relief}

\begin{tabular}{|c|c|c|c|c|c|c|c|c|c|c|c|c|c|c|c|c|c|c|c|c|}
\hline Eve & \multirow{3}{*}{$\begin{array}{l}\text { Date } \\
02 / 15 / 12\end{array}$} & \multirow{3}{*}{$\frac{\text { Window }}{(0,1)}$} & \multirow{3}{*}{$\begin{array}{l}\text { Event } \\
\text { Description(s) } \\
\text { Sen. Reid adds the Pension Funding } \\
\text { Stabilization (PFS) Amendment to MAP- } \\
21 .\end{array}$} & \multirow{3}{*}{$\begin{array}{c}\begin{array}{c}\text { Proability } \\
\text { of Passage }\end{array} \\
\text { Inc. }\end{array}$} & \multicolumn{3}{|c|}{ No $P$} & \multirow{2}{*}{\multicolumn{3}{|c|}{$\begin{array}{c}\text { Lo UF } \\
\text { CAR Std. Error t-stat } \\
\end{array}$}} & \multicolumn{4}{|c|}{ Hi UF } & \multicolumn{3}{|c|}{ [3] - [1] } & \multicolumn{3}{|c|}{ [3] - [2] } \\
\hline No. & & & & & CAR $\mathrm{s}-\mathrm{S}-\mathrm{s}-\mathrm{s}$ & Std. Error & t-stat & & & & CAR & Std. Error & t-stat & & CAR $\mathrm{s}-\mathrm{r}-\mathrm{r}$ & Std. Error & t-stat & CAR & Std. Error & t-stat \\
\hline 1 & & & & & 0.002 & $(0.004)$ & 0.54 & 0.004 & $(0.005)$ & 0.85 & 0.009 & $(0.007)$ & 1.17 & & 0.006 & $(0.005)$ & 1.32 & 0.005 & $(0.005)$ & 0.98 \\
\hline 2 & $03 / 13 / 12$ & $(0,2)$ & $\begin{array}{l}\text { Sen. Boxer amends the PFS Amendment } \\
\text { from } 10 \text { years to } 25 \text { years (3-13). Senate } \\
\text { approves MAP-21 and sends it to the } \\
\text { House of Republicans (3-14). }\end{array}$ & Inc. & 0.005 & $(0.005)$ & 1.04 & 0.009 & $(0.005)$ & $1.79 *$ & 0.016 & $(0.008)$ & 1.85 & * & 0.011 & $(0.006)$ & $1.84 *$ & 0.006 & $(0.006)$ & 1.18 \\
\hline 3 & $03 / 21 / 12$ & $(0,1)$ & $\begin{array}{l}\text { House introduces MAP-21 and } \\
\text { contemporaneously shelves it. }\end{array}$ & Dec. & 0.002 & $(0.004)$ & 0.41 & -0.005 & $(0.004)$ & -1.31 & -0.004 & $(0.007)$ & -0.56 & & -0.005 & $(0.005)$ & -1.11 & 0.002 & $(0.004)$ & 0.35 \\
\hline 4 & $04 / 16 / 12$ & $(0,1)$ & House re-introduces MAP- 21 for debate. & Inc. & 0.002 & $(0.004)$ & 0.49 & 0.005 & $(0.004)$ & 1.20 & 0.009 & $(0.007)$ & 1.38 & & 0.007 & $(0.005)$ & 1.56 & 0.004 & $(0.004)$ & 0.99 \\
\hline 5 & 04/19/12 & $(0,1)$ & $\begin{array}{l}\text { House version of MAP- } 21 \text { is approved } \\
\text { without the PFS Amendement. }\end{array}$ & Dec. & -0.001 & $(0.004)$ & -0.35 & -0.005 & $(0.004)$ & -1.23 & -0.012 & $(0.007)$ & -1.72 & * & -0.010 & $(0.005)$ & $-2.15 * *$ & -0.006 & $(0.004)$ & -1.49 \\
\hline 6 & 06/05/12 & $(0,1)$ & $\begin{array}{l}\text { Sens. Boxer and Inholfe hand-deliver } \\
\text { amended MAP- } 21 \text { to the House (6-5). }\end{array}$ & Inc. & 0.006 & $(0.004)$ & 1.57 & 0.005 & $(0.004)$ & 1.13 & 0.013 & $(0.007)$ & 1.94 & * & 0.008 & $(0.005)$ & 1.48 & 0.009 & $(0.004)$ & $2.05 * *$ \\
\hline 7 & $06 / 27 / 12$ & $(0,3)$ & $\begin{array}{l}\text { Senate leaders reach compromise on } \\
\text { student loan deal (6-27). Senate aides } \\
\text { acknowledge a tentative deal on } \\
\text { transportation bill (6-28). Senate and } \\
\text { House of Republicans approve MAP-21. } \\
\text { Obama commits to signing (6-29). }\end{array}$ & Inc. & 0.008 & $(0.005)$ & 1.48 & 0.014 & $(0.006)$ & $2.23 * *$ & 0.024 & $(0.010)$ & 2.42 & $* *$ & 0.017 & $(0.008)$ & $2.15 * *$ & 0.010 & $(0.006)$ & $1.71 *$ \\
\hline 8 & $07 / 06 / 12$ & $(0,1)$ & $\begin{array}{l}\text { President Obama signs MAP-21, } \\
\text { becomes law. }\end{array}$ & N/A & -0.005 & $(0.004)$ & -1.53 & -0.006 & $(0.004)$ & -1.33 & -0.009 & $(0.007)$ & -1.24 & & -0.003 & $(0.005)$ & -0.61 & -0.003 & $(0.004)$ & -0.69 \\
\hline Net & onormal & Returns & (event no. 1 - 7) & & 0.022 & $(0.011)$ & $2.05 * *$ & 0.026 & $(0.012)$ & $2.11 * *$ & 0.056 & $(0.020)$ & 2.75 & $* *$ & 0.033 & $(0.015)$ & $2.28 * *$ & 0.029 & $(0.013)$ & 2.30 ** \\
\hline
\end{tabular}

***, **, * - Indicates statistical significance at the $1 \%, 5 \%$, and $10 \%$ levels, respectively (two-tailed tests). Abnormal returns are calculated by deducting the CRSP equally weighted market return from the raw return. Standard errors are calculated on a portfolio basis as in Brown and Warner (1985). The sample is partitioned by no ERISA-based pension (No P), the lower three quartiles of Underfund ("Lo UF") and the upper quartile of Underfund ("Hi UF"). 


\begin{tabular}{|c|c|c|c|c|c|c|c|c|c|c|c|c|c|c|}
\hline \multirow{4}{*}{$\begin{array}{l}\text { Event } \\
\text { No. }\end{array}$} & \multirow[b]{4}{*}{ Date } & \multirow[b]{4}{*}{ Window } & \multirow{4}{*}{$\begin{array}{l}\text { Event } \\
\text { Description(s) }\end{array}$} & \multirow{4}{*}{$\begin{array}{l}\text { Proability } \\
\text { of Passage }\end{array}$} & \multicolumn{10}{|c|}{ High pension underfunding by credit rating } \\
\hline & & & & & \multicolumn{3}{|c|}{$[1]$} & & \multicolumn{3}{|c|}{$[2]$} & \multirow{2}{*}{\multicolumn{3}{|c|}{$\begin{array}{c}{[3]} \\
\text { Investment Grade }\end{array}$}} \\
\hline & & & & & \multicolumn{3}{|c|}{ No Credit Rating } & & \multicolumn{3}{|c|}{ Below Investment Grade } & & & \\
\hline & & & & & CAR & Std. Error & t-stat & & CAR & Std. Error & t-stat & CAR & \multicolumn{2}{|c|}{ Std. Error t-stat } \\
\hline 1 & $02 / 15 / 12$ & $(0,1)$ & $\begin{array}{l}\text { Sen. Reid adds the Pension Funding } \\
\text { Stabilization (PFS) Amendment to MAP- } \\
21 \text {. }\end{array}$ & Inc. & 0.006 & $(0.007)$ & 0.85 & & 0.012 & $(0.012)$ & 1.02 & 0.007 & $(0.007)$ & 0.99 \\
\hline 2 & $03 / 13 / 12$ & $(0,2)$ & $\begin{array}{l}\text { Sen. Boxer amends the PFS Amendment } \\
\text { from } 10 \text { years to } 25 \text { years (3-13). Senate } \\
\text { approves MAP- } 21 \text { and sends it to the } \\
\text { House of Republicans (3-14). }\end{array}$ & Inc. & 0.019 & $(0.009)$ & 2.19 & $* *$ & 0.016 & $(0.014)$ & 1.15 & 0.009 & $(0.008)$ & 1.12 \\
\hline 3 & $03 / 21 / 12$ & $(0,1)$ & $\begin{array}{l}\text { House introduces MAP- } 21 \text { and } \\
\text { contemporaneously shelves it. }\end{array}$ & Dec. & 0.001 & $(0.007)$ & 0.10 & & -0.008 & $(0.011)$ & -0.73 & -0.005 & $(0.007)$ & -0.67 \\
\hline 4 & $04 / 16 / 12$ & $(0,1)$ & House re-introduces MAP-21 for debate. & Inc. & 0.014 & $(0.007)$ & 1.98 & $* *$ & 0.006 & $(0.011)$ & 0.55 & 0.007 & $(0.007)$ & 1.02 \\
\hline 5 & $04 / 19 / 12$ & $(0,1)$ & $\begin{array}{l}\text { House version of MAP- } 21 \text { is approved } \\
\text { without the PFS Amendement. }\end{array}$ & Dec. & -0.015 & $(0.007)$ & -2.11 & $* *$ & -0.011 & $(0.011)$ & -0.99 & -0.008 & $(0.007)$ & -1.08 \\
\hline 6 & $06 / 05 / 12$ & $(0,1)$ & $\begin{array}{l}\text { Sens. Boxer and Inholfe hand-deliver } \\
\text { amended MAP-21 to the House (6-5). }\end{array}$ & Inc. & 0.001 & $(0.007)$ & 0.09 & & 0.027 & $(0.011)$ & $2.47 * *$ & 0.012 & $(0.007)$ & $1.66 *$ \\
\hline 7 & $06 / 27 / 12$ & $(0,3)$ & $\begin{array}{l}\text { Senate leaders reach compromise on } \\
\text { student loan deal (6-27). Senate aides } \\
\text { acknowledge a tentative deal on } \\
\text { transportation bill (6-28). Senate and } \\
\text { House of Republicans approve MAP-21. } \\
\text { Obama commits to signing (6-29). }\end{array}$ & Inc. & 0.026 & $(0.010)$ & 2.59 & ** & 0.032 & $(0.016)$ & $2.04 * *$ & 0.007 & $(0.010)$ & 0.74 \\
\hline 8 & $07 / 06 / 12$ & $(0,1)$ & $\begin{array}{l}\text { President Obama signs MAP-21, } \\
\text { becomes law. }\end{array}$ & N/A & -0.004 & $(0.007)$ & -0.56 & & -0.012 & $(0.011)$ & -1.07 & -0.012 & $(0.007)$ & $-1.70 *$ \\
\hline \multicolumn{5}{|c|}{ Net Abnormal Returns (event no. 1 - 7) } & 0.052 & $(0.021)$ & 2.51 & $* *$ & 0.074 & $(0.032)$ & $2.30 * *$ & 0.030 & $(0.020)$ & 1.50 \\
\hline \multicolumn{5}{|c|}{$\mathbf{N}=$} & & 61 & & & & 62 & & & 36 & \\
\hline
\end{tabular}

***, *** * - Indicates statistical significance at the 1\%,5\%, and 10\% levels, respectively (two-tailed tests). Abnormal returns are calculated by deducting the CRSP equally weighted market returns from the raw return. Standard errors are calculated on a portfolio basis as in Brown and Warner (1985). The sample is partitioned by S\&P credit rating. 


\section{Table 2: Descriptive Statistics}

\begin{tabular}{|c|c|c|c|c|}
\hline Variable & Mean & Median & $\sigma$ & $\mathrm{N}$ \\
\hline Underfund & 0.003 & 0.000 & 0.010 & 33,949 \\
\hline$M C$ & 0.001 & 0.000 & 0.004 & 33,949 \\
\hline Post & 0.490 & 0.000 & 0.500 & 33,949 \\
\hline$C A P X$ & 0.013 & 0.007 & 0.016 & 33,949 \\
\hline$R \& D$ & 0.015 & 0.000 & 0.028 & 33,949 \\
\hline Cash Acq. & 0.004 & 0.000 & 0.016 & 33,949 \\
\hline Dividends & 0.003 & 0.000 & 0.005 & 33,949 \\
\hline Repurchases & 0.004 & 0.000 & 0.011 & 33,949 \\
\hline Debt Reduction & 0.022 & 0.000 & 0.051 & 33,266 \\
\hline$P T I$ & -0.001 & 0.013 & 0.063 & 33,895 \\
\hline Leverage & 0.194 & 0.142 & 0.207 & 33,949 \\
\hline$O C F$ & 0.009 & 0.020 & 0.058 & 33,948 \\
\hline Cash & 0.223 & 0.135 & 0.236 & 33,949 \\
\hline Size & 6.293 & 6.291 & 1.967 & 33,949 \\
\hline$M T B$ & 2.179 & 1.545 & 1.765 & 33,949 \\
\hline Working Capital & 0.059 & 0.048 & 0.171 & 33,311 \\
\hline Industry Sigma & 0.383 & 0.327 & 0.287 & 33,465 \\
\hline No Credit Rating & 0.725 & 1.000 & 0.447 & 33,949 \\
\hline Acquisition Count & 364.100 & 206.000 & 484.426 & 33,744 \\
\hline
\end{tabular}

(continued on subsequent page) 
Panel B: Descriptive Stats by Underfunding

\begin{tabular}{|c|c|c|c|c|c|c|c|c|c|c|c|c|c|c|c|c|}
\hline \multirow[b]{2}{*}{ Variable } & \multicolumn{4}{|c|}{ No Pension (No P) [1] } & \multicolumn{4}{|c|}{ Low Underfunding (Lo UF) [2] } & \multicolumn{4}{|c|}{ High Underfunding (Hi UF) [3] } & \multicolumn{3}{|c|}{ Difference } & \multirow[b]{2}{*}{ t-stat } \\
\hline & Mean & Median & $\sigma$ & $\mathrm{N}$ & Mean & Median & $\sigma$ & $\mathrm{N}$ & Mean & Median & $\sigma$ & $\mathrm{N}$ & [3] - [1] & t-stat & {$[3]-[2]$} & \\
\hline Underfund & - & - & - & 25,843 & 0.004 & 0.001 & 0.005 & 6,073 & 0.041 & 0.046 & 0.012 & 2,025 & - & - & 0.037 & 134.71 \\
\hline$M C$ & - & - & - & 25,843 & 0.004 & 0.002 & 0.005 & 6,073 & 0.013 & 0.013 & 0.006 & 2,025 & - & - & 0.009 & 60.30 \\
\hline Pcont & - & - & - & - & 0.002 & 0.001 & 0.004 & 2,270 & 0.005 & 0.003 & 0.009 & 966 & - & - & 0.003 & 11.11 \\
\hline Post & - & - & - & 25,843 & 0.499 & 0.000 & 0.500 & 6,073 & 0.461 & 0.000 & 0.499 & 2,025 & 0.461 & 41.58 & -0.038 & -2.98 \\
\hline$C A P X$ & 0.013 & 0.007 & 0.017 & 25,843 & 0.012 & 0.008 & 0.011 & 6,073 & 0.010 & 0.008 & 0.008 & 2,025 & -0.003 & -13.36 & -0.001 & -5.41 \\
\hline$R \& D$ & 0.018 & 0.000 & 0.031 & 25,843 & 0.003 & 0.000 & 0.007 & 6,073 & 0.004 & 0.000 & 0.011 & 2,025 & -0.014 & -44.98 & 0.001 & 3.70 \\
\hline Cash Acq. & 0.004 & 0.000 & 0.016 & 25,843 & 0.005 & 0.000 & 0.017 & 6,073 & 0.004 & 0.000 & 0.014 & 2,025 & 0.000 & -1.40 & -0.002 & -4.39 \\
\hline Dividends & 0.002 & 0.000 & 0.005 & 25,843 & 0.005 & 0.003 & 0.006 & 6,073 & 0.003 & 0.001 & 0.004 & 2,025 & 0.001 & 6.47 & -0.002 & -14.05 \\
\hline Repurchases & 0.004 & 0.000 & 0.010 & 25,843 & 0.006 & 0.000 & 0.011 & 6,073 & 0.003 & 0.000 & 0.008 & 2,025 & 0.000 & -2.19 & -0.003 & -12.44 \\
\hline Debt Reduction & 0.021 & 0.000 & 0.051 & 25,395 & 0.025 & 0.002 & 0.050 & 5,892 & 0.029 & 0.002 & 0.056 & 1,971 & 0.008 & 6.54 & 0.004 & 2.64 \\
\hline$P T I$ & -0.007 & 0.010 & 0.069 & 25,801 & 0.020 & 0.020 & 0.027 & 6,063 & 0.012 & 0.014 & 0.028 & 2,023 & 0.020 & 26.30 & -0.008 & -10.77 \\
\hline Leverage & 0.174 & 0.087 & 0.212 & 25,843 & 0.258 & 0.239 & 0.173 & 6,073 & 0.255 & 0.237 & 0.180 & 2,025 & 0.080 & 19.05 & -0.003 & -0.70 \\
\hline$O C F$ & 0.005 & 0.018 & 0.063 & 25,842 & 0.025 & 0.025 & 0.031 & 6,073 & 0.016 & 0.018 & 0.036 & 2,025 & 0.011 & 12.59 & -0.009 & -9.82 \\
\hline Cash & 0.262 & 0.180 & 0.253 & 25,843 & 0.101 & 0.076 & 0.095 & 6,073 & 0.095 & 0.070 & 0.088 & 2,025 & -0.167 & -66.57 & -0.007 & -2.92 \\
\hline Size & 5.864 & 5.838 & 1.824 & 25,843 & 7.982 & 8.036 & 1.663 & 6,073 & 6.703 & 6.718 & 1.742 & 2,025 & 0.839 & 20.80 & -1.278 & -28.92 \\
\hline$M T B$ & 2.357 & 1.626 & 1.943 & 25,843 & 1.652 & 1.456 & 0.758 & 6,073 & 1.455 & 1.312 & 0.582 & 2,025 & -0.903 & -50.98 & -0.197 & -12.20 \\
\hline Working Capital & 0.047 & 0.031 & 0.181 & 25,375 & 0.092 & 0.079 & 0.130 & 5,933 & 0.118 & 0.110 & 0.127 & 1,996 & 0.071 & 23.25 & 0.026 & 7.78 \\
\hline Industry Sigma & 0.408 & 0.347 & 0.289 & 25,470 & 0.307 & 0.196 & 0.270 & 5,989 & 0.282 & 0.196 & 0.244 & 1,997 & -0.127 & -22.02 & -0.025 & -3.91 \\
\hline No Credit Rating & 0.836 & 1.000 & 0.370 & 25,843 & 0.344 & 0.000 & 0.475 & 6,073 & 0.420 & 0.000 & 0.494 & 2,025 & -0.416 & -37.11 & 0.076 & 6.05 \\
\hline$M \& A$ Count & 413.993 & 224.000 & 517.811 & 25,675 & 205.750 & 148.667 & 301.164 & 6,037 & 204.236 & 101.333 & 329.218 & 2,025 & -209.758 & -26.23 & -1.515 & -0.18 \\
\hline
\end{tabular}

Underfund is a continuous variable measuring the level of ERISA pension underfunding (ERISA pension liabilities - ERISA pension assets) scaled by lagged assets. $M C$ is the ERISA-based annual mandatory contributions scaled by total assets. Pcont is the quarterly total pension contributions scaled by total assets. Post is an indicator variable equal to $1(0)$ when the quarter end date is after (before) July 6,2012. CAPX is capital expenditures scaled by lagged assets. $R \& D$ is research and development expenses scaled by lagged assets. Cash Acq. is cash expenditures for acquisitions scaled by lagged assets. Dividends is dividends scaled by lagged assets. Repurchases is stock repurchases scaled by lagged assets. Debt Reduction is debt reduction from the statement of cash flows scaled by lagged assets. PTI is pretax income scaled by lagged assets. OCF is cash flow from operating activities scaled by lagged assets. Cash is cash and short term investments scaled by lagged assets. Size is the natural log of the market value of equity. $M T B$ is calculated as the market value of equity + book assets - stockholders' equity scaled by lagged assets. Leverage is the book value of long term debt scaled by lagged assets. Working Capital is current assets excluding cash - current liabilities scaled by total assets. Industry Sigma is the standard deviation of operating cash flows scaled by lagged assets by two-digit SIC industry. No Credit Rating is an indicator variable equal to 1 when the firm does not have a credit rating from S\&P (per Compustat), and is equal to zero otherwise. M\&A Count is the average number of acqusitions per two digit industry quarter (per SDC) over the past three years. The sample is partitioned by no ERISA-based pension ("No P"), lower three quartiles of Underfund ("Lo UF") and upper quartile of Underfund ("Hi UF"). 
Table 3: Pension Funding Difference-in-Differences

Panel A: Difference in means by subgroup

[A]

\begin{tabular}{|c|c|c|c|}
\hline No P [1] & \multicolumn{3}{|c|}{ Pre-MAP-21 } \\
\hline Variable & Mean & Std & $\mathrm{N}$ \\
\hline$C A P X$ & 0.013 & 0.017 & 13,193 \\
\hline$R \& D$ & 0.017 & 0.030 & 13,193 \\
\hline Cash Acq. & 0.004 & 0.016 & 13,193 \\
\hline Repurchases & 0.004 & 0.011 & 13,193 \\
\hline Dividends & 0.002 & 0.005 & 13,193 \\
\hline Debt Reduction & 0.019 & 0.050 & 12,956 \\
\hline
\end{tabular}

Low UF [2]

Variable

CAPX

$R \& D$

Cash Acq.

Repurchases

Dividends

Debt Reduction

\begin{tabular}{clc}
\multicolumn{3}{c}{ Pre-MAP-21 } \\
\hline Mean & Std & $\mathrm{N}$ \\
\hline 0.011 & 0.011 & 3,043 \\
0.003 & 0.007 & 3,043 \\
0.006 & 0.017 & 3,043 \\
0.007 & 0.012 & 3,043 \\
0.004 & 0.005 & 3,043 \\
0.024 & 0.050 & 2,944
\end{tabular}

High UF [3]

Variable

\begin{tabular}{ccc}
\multicolumn{3}{c}{ Pre-MAP-21 } \\
\cline { 2 - 3 } Mean & Std & $\mathrm{N}$ \\
\hline 0.010 & 0.008 & 1,092 \\
0.004 & 0.010 & 1,092 \\
0.004 & 0.015 & 1,092 \\
0.003 & 0.008 & 1,092 \\
0.003 & 0.004 & 1,092 \\
0.027 & 0.054 & 1,057
\end{tabular}

[B]

\begin{tabular}{ccc}
\multicolumn{3}{c}{ Post-MAP-21 } \\
\hline Mean & Std & $\mathrm{N}$ \\
\hline 0.013 & 0.017 & 12,650 \\
0.019 & 0.031 & 12,650 \\
0.004 & 0.016 & 12,650 \\
0.004 & 0.010 & 12,650 \\
0.002 & 0.006 & 12,650 \\
0.022 & 0.052 & 12,439
\end{tabular}

\begin{tabular}{clc}
\multicolumn{3}{c}{ Post-MAP-21 } \\
\hline Mean & Std & $\mathrm{N}$ \\
\hline 0.012 & 0.011 & 3,030 \\
0.004 & 0.007 & 3,030 \\
0.005 & 0.017 & 3,030 \\
0.006 & 0.011 & 3,030 \\
0.005 & 0.006 & 3,030 \\
0.027 & 0.050 & 2,948
\end{tabular}

\begin{tabular}{cll}
\multicolumn{3}{c}{ Post-MAP-21 } \\
\hline Mean & Std & $\mathrm{N}$ \\
\hline 0.011 & 0.008 & 933 \\
0.005 & 0.011 & 933 \\
0.004 & 0.014 & 933 \\
0.004 & 0.009 & 933 \\
0.003 & 0.004 & 933 \\
0.031 & 0.057 & 914
\end{tabular}

$[\mathrm{C}]$

\begin{tabular}{|c|c|c|}
\hline \multicolumn{3}{|c|}{ Difference in Means } \\
\hline$[\mathrm{B}]-[\mathrm{A}]$ & $\mathrm{SE}$ & $\mathrm{t}$ \\
\hline 0.0000 & 0.0002 & 0.13 \\
\hline 0.0013 & 0.0004 & $3.31 * * *$ \\
\hline 0.0000 & 0.0002 & -0.04 \\
\hline-0.0004 & 0.0001 & $-3.14 * * *$ \\
\hline 0.0006 & 0.0001 & $8.63 *$ \\
\hline 0.0024 & 0.0006 & $3.79 * * *$ \\
\hline
\end{tabular}

\begin{tabular}{rcc}
\multicolumn{4}{c}{ Difference in Means } \\
\hline [B] - [A] & SE & $\mathrm{t}$ \\
\hline 0.0003 & 0.0003 & 1.09 \\
0.0002 & 0.0002 & 0.96 \\
-0.0003 & 0.0004 & -0.77 \\
-0.0006 & 0.0003 & -2.18 \\
0.0005 & 0.0001 & 3.63 \\
$* * *$ \\
0.0030 & 0.0013 & 2.27
\end{tabular}$* *$

\begin{tabular}{rcc}
\multicolumn{4}{c}{ Difference in Means } \\
\hline$[\mathrm{B}]-[\mathrm{A}]$ & $\mathrm{SE}$ & $\mathrm{t}$ \\
\hline 0.0003 & 0.0004 & 0.88 \\
0.0006 & 0.0005 & 1.20 \\
0.0000 & 0.0006 & 0.03 \\
0.0011 & 0.0004 & 3.05 \\
0.0001 & 0.0002 & 0.73 \\
0.0035 & 0.0025 & 1.37
\end{tabular}

Panel B: Difference-in-differences

\begin{tabular}{|c|c|c|c|c|c|c|}
\hline \multirow[b]{2}{*}{ Variable } & \multicolumn{3}{|c|}{ Hi UF [3] vs. No P [1] } & \multicolumn{3}{|c|}{ Hi UF [3] vs. Lo UF [2] } \\
\hline & DiD & $\mathrm{SE}$ & $\mathrm{t}$ & $\mathrm{DiD}$ & SE & $\mathrm{t}$ \\
\hline$C A P X$ & 0.0003 & 0.0004 & 0.70 & 0.0000 & 0.0005 & 0.03 \\
\hline$R \& D$ & -0.0007 & 0.0006 & -1.13 & 0.0004 & 0.0005 & 0.77 \\
\hline Cash Acq. & 0.0000 & 0.0007 & -0.01 & 0.0003 & 0.0008 & 0.41 \\
\hline Repurchases & 0.0016 & 0.0004 & $3.91 * * *$ & 0.0018 & 0.0005 & $3.75 *$ \\
\hline Dividends & -0.0004 & 0.0002 & $-2.14 * *$ & -0.0004 & 0.0002 & -1.59 \\
\hline Debt Reduction & 0.0010 & 0.0026 & 0.39 & 0.0005 & 0.0028 & 0.18 \\
\hline
\end{tabular}

$C A P X$ is capital expenditures scaled by lagged assets. $R \& D$ is research and development expenses scaled by lagged assets. Cash Acq. is cash expenditures for acquisitions scaled by lagged assets. Dividends is dividends scaled by lagged assets. Repurchases is stock repurchases scaled by lagged assets. Debt Reduction is debt reduction from the statement of cash flows scaled by lagged assets. Pre MAP-21 observations occur between April 1, 2011 and July 6, 2012. Post MAP-21 observations occur between July 6, 2012 and September 30, 2013. The sample is partitioned by no ERISA-based pension ("No P"), lower three quartiles of Underfund ("Lo UF") and upper quartile of Underfund ("Hi UF").

$* * *, * *, *$ - Indicates statistical significance at the $1 \%, 5 \%$, and $10 \%$ levels, respectively (two-tailed tests). 
Table 4: Pension Funding Relief (Underfund) Multivariate Analysis

\begin{tabular}{|c|c|c|c|c|c|c|c|c|c|c|c|c|}
\hline \multirow[b]{3}{*}{ Independent Variable } & \multicolumn{2}{|l|}{ [1] } & \multicolumn{2}{|l|}{$[2]$} & \multicolumn{2}{|l|}{ [3] } & \multicolumn{2}{|l|}{ [4] } & [5] & \multicolumn{3}{|c|}{$[6]$} \\
\hline & \multicolumn{6}{|c|}{ Investment Dependent Variables } & \multicolumn{6}{|c|}{ Payout Policy Dependent Variables } \\
\hline & $\begin{array}{c}C A P X \\
\text { Coeff. } \\
\text { (p-value) }\end{array}$ & & $\begin{array}{c}R \& D \\
\text { Coeff. } \\
\text { (p-value) }\end{array}$ & & $\begin{array}{c}\text { Cash Acq. } \\
\text { Coeff. } \\
\text { (p-value) } \\
\end{array}$ & & $\begin{array}{c}\text { Repurchases } \\
\text { Coeff. } \\
\text { (p-value) } \\
\end{array}$ & & $\begin{array}{c}\text { Dividends } \\
\text { Coeff. } \\
\text { (p-value) } \\
\end{array}$ & & $\begin{array}{l}\text { ebt Reductio } \\
\text { Coeff. } \\
\text { (p-value) } \\
\end{array}$ & \\
\hline Intercept & $\begin{array}{l}-0.005 \\
(0.074)\end{array}$ & $*$ & $\begin{array}{c}0.028 \\
<(0.001)\end{array}$ & $* * *$ & $\begin{array}{c}0.009 \\
(0.064)\end{array}$ & $*$ & $\begin{array}{c}-0.005 \\
(0.032)\end{array}$ & $* *$ & $\begin{array}{l}-0.001 \\
(0.547)\end{array}$ & & $\begin{array}{c}0.012 \\
(0.315)\end{array}$ & \\
\hline Post & $\begin{array}{c}0.000 \\
(0.375)\end{array}$ & & $\begin{array}{c}0.001 \\
<(0.001)\end{array}$ & $* * *$ & $\begin{array}{c}0.000 \\
(0.029)\end{array}$ & $* *$ & $\begin{array}{c}0.000 \\
<(0.001)\end{array}$ & $* * *$ & $\begin{array}{c}0.000 \\
<(0.001)\end{array}$ & $* * *$ & $\begin{array}{c}0.285 \\
(0.252)\end{array}$ & \\
\hline Underfund & $\begin{array}{c}0.177 \\
(0.002)\end{array}$ & $* * *$ & $\begin{array}{l}-0.122 \\
(0.014)\end{array}$ & $* *$ & $\begin{array}{c}0.473 \\
<(0.001)\end{array}$ & $* * *$ & $\begin{array}{c}0.043 \\
(0.402)\end{array}$ & & $\begin{array}{c}0.047 \\
(0.007)\end{array}$ & $* * *$ & $\begin{array}{c}0.001 \\
(0.008)\end{array}$ & **** \\
\hline Post $\times$ Underfund & $\begin{array}{c}0.022 \\
(0.022)\end{array}$ & $* *$ & $\begin{array}{c}0.004 \\
(0.668)\end{array}$ & & $\begin{array}{c}0.003 \\
(0.846)\end{array}$ & & $\begin{array}{c}0.024 \\
(0.006)\end{array}$ & $* * *$ & $\begin{array}{l}-0.004 \\
(0.203)\end{array}$ & & $\begin{array}{c}0.071 \\
(0.091)\end{array}$ & $*$ \\
\hline$O C F$ & $\begin{array}{c}0.011 \\
<(0.001)\end{array}$ & $* * *$ & $\begin{array}{c}-0.012 \\
<(0.001)\end{array}$ & $* * *$ & $\begin{aligned} & 0.009 \\
< & (0.001)\end{aligned}$ & $* * *$ & $\begin{array}{c}0.004 \\
(0.001)\end{array}$ & $* * *$ & $\begin{array}{c}0.002 \\
<(0.001)\end{array}$ & $* * *$ & $\begin{array}{c}0.018 \\
(0.002)\end{array}$ & $* * *$ \\
\hline Cash & $\begin{array}{c}0.002 \\
(0.009)\end{array}$ & $* * *$ & $\begin{array}{c}-0.006 \\
<(0.001)\end{array}$ & $* * *$ & $\begin{array}{c}0.031 \\
<(0.001)\end{array}$ & $* * *$ & $\begin{array}{c}0.004 \\
<(0.001)\end{array}$ & $* * *$ & $\begin{array}{c}0.001 \\
<(0.001)\end{array}$ & $* * *$ & $\begin{array}{l}-0.004 \\
(0.204)\end{array}$ & \\
\hline Size & $\begin{array}{c}0.002 \\
<(0.001)\end{array}$ & $* * *$ & $\begin{array}{c}-0.004 \\
<(0.001)\end{array}$ & $* * *$ & $\begin{array}{c}0.000 \\
(0.856)\end{array}$ & & $\begin{array}{c}0.001 \\
<(0.001)\end{array}$ & $* * *$ & $\begin{array}{c}0.000 \\
<(0.001)\end{array}$ & $* * *$ & $\begin{array}{l}-0.002 \\
(0.039)\end{array}$ & $* *$ \\
\hline$M T B$ & $\begin{array}{c}0.001 \\
<(0.001)\end{array}$ & $* * *$ & $\begin{array}{c}0.003 \\
<(0.001)\end{array}$ & $* * *$ & $\begin{array}{c}0.001 \\
<(0.001)\end{array}$ & $* * *$ & $\begin{array}{c}0.000 \\
(0.002)\end{array}$ & $* * *$ & $\begin{array}{c}0.000 \\
(0.784)\end{array}$ & & $\begin{array}{c}0.001 \\
(0.001)\end{array}$ & $* * *$ \\
\hline Leverage & $\begin{array}{c}-0.007 \\
<(0.001)\end{array}$ & $* * *$ & $\begin{array}{l}-0.002 \\
(0.001)\end{array}$ & $* * *$ & $\begin{array}{c}-0.013 \\
<(0.001)\end{array}$ & $* * *$ & $\begin{array}{c}-0.006 \\
<(0.001)\end{array}$ & $* * *$ & $\begin{array}{c}-0.002 \\
<(0.001)\end{array}$ & $* * *$ & $\begin{array}{c}0.041 \\
<(0.001)\end{array}$ & *** \\
\hline Firm Fixed Effects & $\mathrm{Y}$ & & $\mathrm{Y}$ & & $\mathrm{Y}$ & & $\mathrm{Y}$ & & $\mathrm{Y}$ & & $\mathrm{Y}$ & \\
\hline $\mathrm{R}^{2}$ & $73.8 \%$ & & $93.16 \%$ & & $21.06 \%$ & & $50.01 \%$ & & $77.77 \%$ & & $51.85 \%$ & \\
\hline $\mathrm{N}$ & 33,939 & & 33,939 & & 33,939 & & 33,939 & & 33,939 & & 33,257 & \\
\hline
\end{tabular}

Underfund is a continuous variable measuring the level of ERISA pension underfunding (ERISA pension liabilities ERISA pension assets) scaled by lagged assets. Post is an indicator variable equal to $1(0)$ when the quarter end date is after (before) July 6, 2012. $C A P X$ is capital expenditures scaled by lagged assets. $R \& D$ is research and development expenses scaled by lagged assets. Cash Acq. is cash expenditures for acquisitions scaled by lagged assets. Dividends is dividends scaled by lagged assets. Repurchases is stock repurchases scaled by lagged assets. Debt Reduction is debt reduction from the statement of cash flows scaled by lagged assets. $O C F$ is cash flow from operating activities scaled by lagged assets. Cash is cash and short term investments scaled by lagged assets. Size is the natural log of the market value of equity. $M T B$ is calculated as market value of equity + book assets - stockholders' equity scaled by lagged assets. Leverage is the book value of long term debt scaled by lagged assets. ***, **, * - Statistically significant at the $1 \%, 5 \%$, and $10 \%$ level, respectively, using two-tailed standard errors. 
Table 5: Pension Funding Relief (MC) Multivariate Analysis

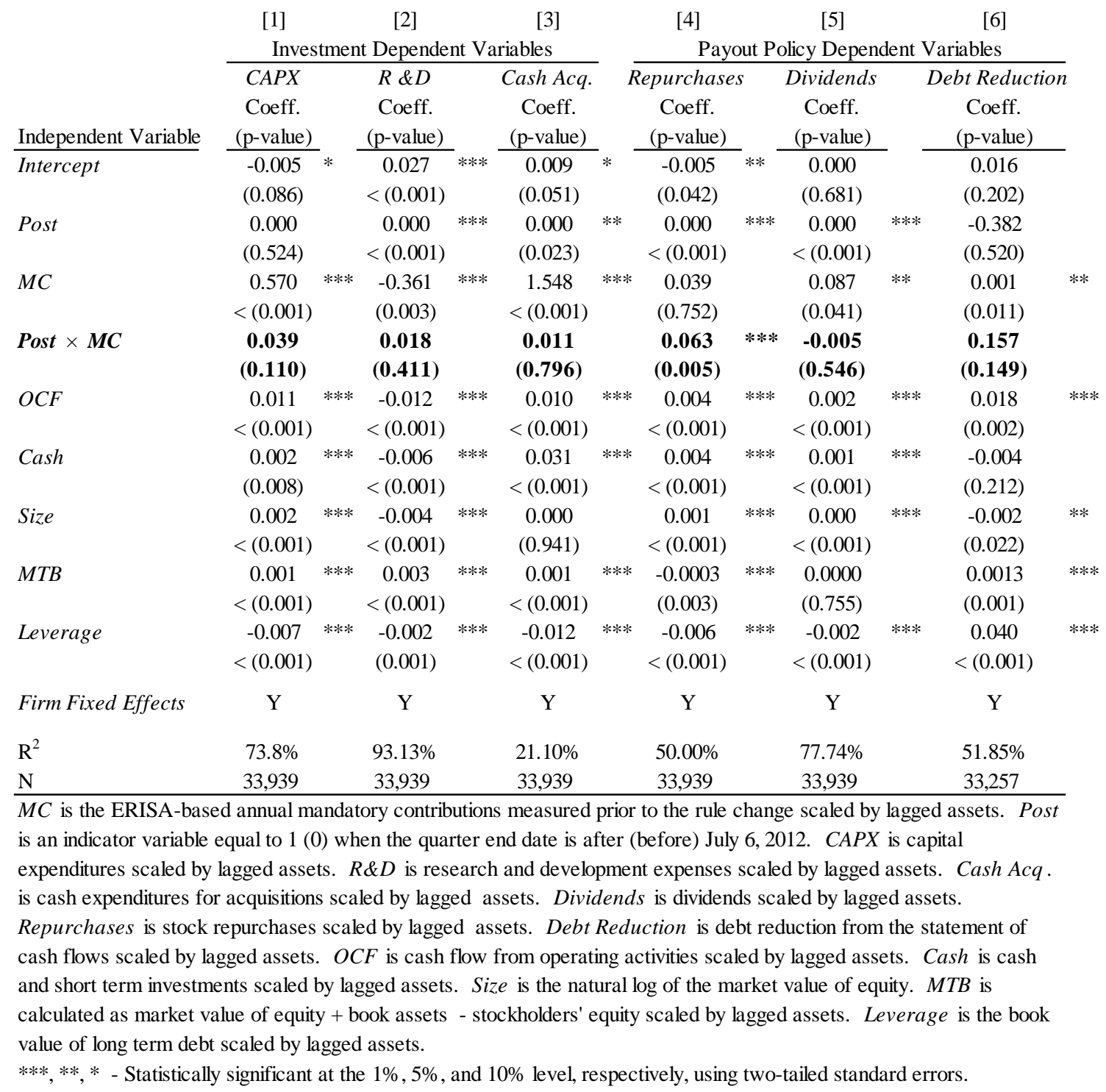


Table 6: The Effect of Pension Funding Relief of Cash Holdings

\begin{tabular}{|c|c|c|c|c|}
\hline \multirow[b]{3}{*}{ Independent Variable } & [1] & \multicolumn{2}{|r|}{$[2]$} & \\
\hline & \multicolumn{3}{|c|}{$\begin{array}{c}\text { Dep. Variable }=\text { Cash } \\
\text { Proxy for Funding Relief }\end{array}$} & \\
\hline & $\begin{array}{c}\text { Underfund } \\
\text { Coeff. } \\
\text { (p-value) }\end{array}$ & & $\begin{array}{c}M C \\
\text { Coeff. } \\
\text { (p-value) } \\
\end{array}$ & \\
\hline Intercept & $\begin{array}{l}-0.006 \\
(0.769)\end{array}$ & & $\begin{array}{l}-0.001 \\
(0.976)\end{array}$ & \\
\hline Post & $\begin{array}{c}-0.011 \\
<(0.001)\end{array}$ & $* * *$ & $\begin{array}{c}-0.011 \\
<(0.001)\end{array}$ & $* * *$ \\
\hline Pension Funding Relief & $\begin{array}{c}1.354 \\
(0.001)\end{array}$ & $* * *$ & $\begin{array}{c}2.739 \\
(0.005)\end{array}$ & $* * *$ \\
\hline Post $\times$ Pension Funding Relief & $\begin{aligned} & 0.340 \\
< & (0.001)\end{aligned}$ & $* * *$ & $\begin{aligned} & 0.924 \\
< & (0.001)\end{aligned}$ & $* * *$ \\
\hline$M T B$ & $\begin{array}{c}0.003 \\
(0.001)\end{array}$ & $* * *$ & $\begin{array}{c}0.003 \\
<(0.001)\end{array}$ & $* * *$ \\
\hline Size & $\begin{aligned} & 0.009 \\
< & (0.001)\end{aligned}$ & $* * *$ & $\begin{aligned} & 0.009 \\
< & (0.001)\end{aligned}$ & $* * *$ \\
\hline$O C F$ & $\begin{array}{c}0.330 \\
<(0.001)\end{array}$ & $* * *$ & $\begin{aligned} & 0.330 \\
< & (0.001)\end{aligned}$ & $* * *$ \\
\hline Working Capital & $\begin{array}{c}-0.130 \\
<(0.001)\end{array}$ & $* * *$ & $\begin{array}{c}-0.130 \\
<(0.001)\end{array}$ & $* * *$ \\
\hline$R \& D$ & $\begin{array}{c}0.050 \\
(0.347)\end{array}$ & & $\begin{array}{c}0.049 \\
(0.357)\end{array}$ & $* * *$ \\
\hline Firm Fixed Effects & $\mathrm{Y}$ & & $\mathrm{Y}$ & \\
\hline $\mathrm{R}^{2}$ & $93.7 \%$ & & $93.69 \%$ & \\
\hline $\mathrm{N}$ & 33,942 & & 33,942 & \\
\hline
\end{tabular}

Pension Funding Relief in Table 6 is measured by Underfund and MC. Underfund is a continuous variable measuring the level of ERISA pension underfunding (ERISA pension liabilities - ERISA pension assets) scaled by lagged assets. $M C$ is the ERISA-based annual mandatory contributions measured prior to the rule change scaled by lagged assets. Post is an indicator variable equal to 1 (0) when the quarter end date is after (before) July 6, 2012. Cash is cash and short term investments scaled by lagged assets. MTB is calculated as market value of equity + book assets - stockholders' equity scaled by lagged assets. Size is the natural log of the market value of equity. $O C F$ is cash flow from operating activities scaled by lagged assets. Working Capital is current assets excluding cash current liabilities scaled by total assets. $R \& D$ is lagged research and development expenses scaled by lagged assets. $* * *, * *, *$ - Statistically significant at the $1 \%, 5 \%$, and $10 \%$ level, respectively, using two-tailed standard errors. 


\section{Table 7: Pension Funding Relief and Financial Constraints}

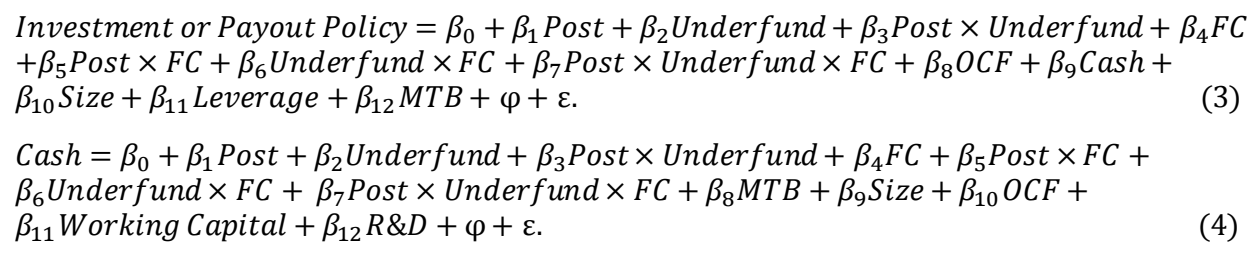

\begin{tabular}{|c|c|c|c|c|c|c|c|c|c|}
\hline \multirow[b]{4}{*}{ Dependent Variable } & & {$[1]$} & & {$[2]$} & & {$[3]$} & & {$[4]$} & \\
\hline & & \multicolumn{7}{|c|}{ Proxy for Financing Constraint $(F C)$} & \\
\hline & & \multicolumn{4}{|c|}{ No Credit Rating } & \multicolumn{3}{|c|}{ Sigma Rank } & \\
\hline & Equation & $\begin{array}{c}\hat{\beta}_{3} \\
\text { Coeff. } \\
\text { (p-value) }\end{array}$ & & $\begin{array}{c}\hat{\beta}_{7} \\
\text { Coeff. } \\
\text { (p-value) }\end{array}$ & & $\begin{array}{c}\hat{\beta}_{3} \\
\text { Coeff. } \\
\text { (p-value) }\end{array}$ & & $\begin{array}{c}\hat{\beta}_{7} \\
\text { Coeff. } \\
\text { (p-value) }\end{array}$ & \\
\hline$C A P X$ & (3) & $\begin{array}{c}0.023 \\
(0.072)\end{array}$ & $*$ & $\begin{array}{l}-0.001 \\
(0.969)\end{array}$ & & $\begin{array}{c}0.012 \\
(0.438)\end{array}$ & & $\begin{array}{c}0.004 \\
(0.629)\end{array}$ & \\
\hline$R \& D$ & (3) & $\begin{array}{c}0.008 \\
(0.486)\end{array}$ & & $\begin{array}{l}-0.010 \\
(0.554)\end{array}$ & & $\begin{array}{l}-0.003 \\
(0.830)\end{array}$ & & $\begin{array}{c}0.009 \\
(0.280)\end{array}$ & \\
\hline Cash Acq. & (3) & $\begin{array}{c}0.021 \\
(0.346)\end{array}$ & & $\begin{array}{l}-0.037 \\
(0.270)\end{array}$ & & $\begin{array}{c}0.049 \\
(0.059)\end{array}$ & $*$ & $\begin{array}{l}-0.032 \\
(0.038)\end{array}$ & $* *$ \\
\hline Repurchases & (3) & $\begin{array}{c}0.032 \\
(0.007)\end{array}$ & $* * *$ & $\begin{array}{l}-0.016 \\
(0.370)\end{array}$ & & $\begin{array}{c}0.012 \\
(0.374)\end{array}$ & & $\begin{array}{c}0.010 \\
(0.234)\end{array}$ & \\
\hline Dividends & (3) & $\begin{array}{l}-0.007 \\
(0.076)\end{array}$ & $*$ & $\begin{array}{c}0.005 \\
(0.398)\end{array}$ & & $\begin{array}{l}-0.003 \\
(0.477)\end{array}$ & & $\begin{array}{c}0.000 \\
(0.994)\end{array}$ & \\
\hline Debt Reduction & (3) & $\begin{array}{c}0.004 \\
(0.942)\end{array}$ & & $\begin{array}{c}0.119 \\
(0.173)\end{array}$ & & $\begin{array}{c}0.181 \\
(0.006)\end{array}$ & $* * *$ & $\begin{array}{l}-0.102 \\
(0.013)\end{array}$ & $* *$ \\
\hline Cash & (4) & $\begin{array}{c}0.107 \\
(0.246) \\
\end{array}$ & & $\begin{array}{c}0.335 \\
(0.017) \\
\end{array}$ & $* *$ & $\begin{array}{c}0.061 \\
(0.568) \\
\end{array}$ & & $\begin{array}{c}0.231 \\
<(0.001) \\
\end{array}$ & $* * *$ \\
\hline
\end{tabular}

(continued on subsequent page)

Table 7 reports the coefficients $\beta_{3}$ and $\beta_{7}$ for equation (3) with investment and payout policy as the dependent variable and the coefficients $\beta_{3}$ and $\beta_{7}$ for equation (4) with cash as the dependent variable. Underfund is a continuous variable measuring the level of ERISA pension underfunding (ERISA pension liabilities - ERISA pension assets) scaled by lagged assets. Post is an indicator variable equal to $1(0)$ when the quarter end date is after (before) July 6, 2012. CAPX is capital investments scaled by lagged assets. $R \& D$ is research and development expenses scaled by lagged assets. Cash Acq. is cash expenditures for acquisitions scaled by lagged assets. Repurchases is stock repurchases scaled by lagged assets. Debt Reduction is debt reduction from the statement of cash flows scaled by lagged assets. OCF is cash flow from operating activities scaled by lagged assets. Cash is cash and short term investments scaled by lagged assets. Size is the natural $\log$ of the market value of equity. $M T B$ is calculated as the market value of equity + book assets stockholders' equity scaled by lagged assets. Leverage is the book value of long term debt scaled by lagged assets. Working Capital is current assets excluding cash - current liabilities scaled by total assets. $F C$ is an indicator variable proxied by two different variables in columns [1] through [4]. In columns [1] and [2], FC is an indicator variable equal to 1 when the observation does not have an S\&P credit rating, and is equal to zero otherwise. In columns [3] and [4], FC is the quartile rank of the Industry Sigma for the year. Industry Sigma is the standard deviation of operating cash flows scaled by lagged assets by two-digit SIC industry.

$* * *, * *, *$ - Statistically significant at the $1 \%, 5 \%$, and $10 \%$ level, respectively, using two-tailed standard errors. 


\section{Table 8: Pension Funding Relief, Secondary Market Liquidity, and Growth Options}

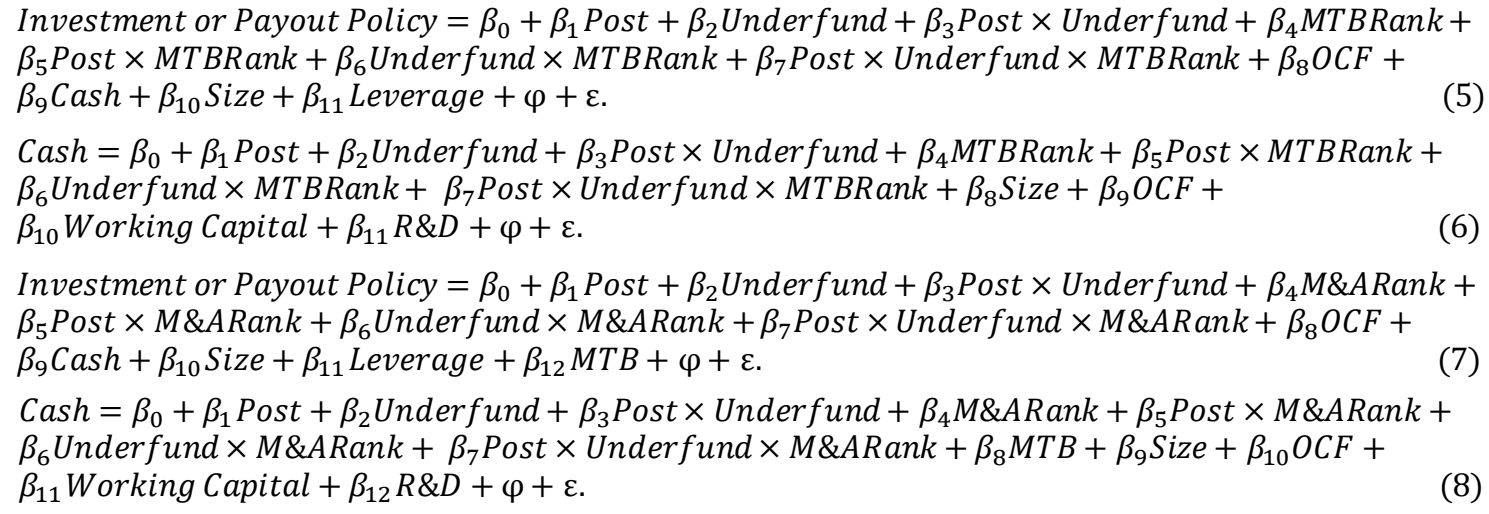

Cash $=\beta_{0}+\beta_{1}$ Post $+\beta_{2}$ Underfund $+\beta_{3}$ Post $\times$ Underfund $+\beta_{4}$ MTBRank $+\beta_{5}$ Post $\times$ MTBRank + $\beta_{6}$ Underfund $\times$ MTBRank $+\beta_{7}$ Post $\times$ Underfund $\times$ MTBRank $+\beta_{8}$ Size $+\beta_{9}$ OCF +

$\beta_{10}$ Working Capital $+\beta_{11} R \& D+\varphi+\varepsilon$.

Investment or Payout Policy $=\beta_{0}+\beta_{1}$ Post $+\beta_{2}$ Underfund $+\beta_{3}$ Post $\times$ Underfund $+\beta_{4} M \& A R a n k+$ $\beta_{5}$ Post $\times M \& A$ Rank $+\beta_{6}$ Underfund $\times M \& A$ Rank $+\beta_{7}$ Post $\times$ Underfund $\times M \& A R a n k+\beta_{8} O C F+$ $\beta_{9}$ Cash $+\beta_{10}$ Size $+\beta_{11}$ Leverage $+\beta_{12} M T B+\varphi+\varepsilon$.

Cash $=\beta_{0}+\beta_{1}$ Post $+\beta_{2}$ Underfund $+\beta_{3}$ Post $\times$ Underfund $+\beta_{4} M \& A$ Rank $+\beta_{5}$ Post $\times$ M\&ARank + $\beta_{6}$ Underfund $\times M \& A$ Rank $+\beta_{7}$ Post $\times$ Underfund $\times M \& A R a n k+\beta_{8} M T B+\beta_{9}$ Size $+\beta_{10} O C F+$ $\beta_{11}$ Working Capital $+\beta_{12} R \& D+\varphi+\varepsilon$.

\begin{tabular}{|c|c|c|c|c|c|c|c|c|c|c|}
\hline \multirow[b]{3}{*}{ Dependent Variable } & \multirow[b]{3}{*}{ Equation } & \multirow{2}{*}{\multicolumn{3}{|c|}{${ }_{\text {MTBRank }}^{[1]}$}} & & & \multicolumn{2}{|l|}{$[3]$} & \multicolumn{2}{|l|}{$[4]$} \\
\hline & & & & & & & $M \&$ & \&AR & ank & \\
\hline & & $\begin{array}{c}\hat{\beta}_{3} \\
\text { Coeff. } \\
\text { (p-value) }\end{array}$ & & $\begin{array}{c}\hat{\beta}_{7} \\
\text { Coeff. } \\
\text { (p-value) }\end{array}$ & & Equation & $\begin{array}{c}\hat{\beta}_{3} \\
\text { Coeff. } \\
\text { (p-value) }\end{array}$ & & $\begin{array}{c}\hat{\beta}_{7} \\
\text { Coeff. } \\
\text { (p-value) }\end{array}$ & \\
\hline$C A P X$ & (5) & $\begin{array}{c}0.019 \\
(0.211)\end{array}$ & & $\begin{array}{c}0.006 \\
(0.583)\end{array}$ & & (7) & $\begin{array}{l}-0.007 \\
(0.599)\end{array}$ & & $\begin{array}{c}0.018 \\
(0.053)\end{array}$ & $*$ \\
\hline$R \& D$ & (5) & $\begin{array}{l}-0.012 \\
(0.377)\end{array}$ & & $\begin{array}{c}0.021 \\
(0.035)\end{array}$ & $* *$ & (7) & $\begin{array}{l}-0.005 \\
(0.699)\end{array}$ & & $\begin{array}{c}0.007 \\
(0.405)\end{array}$ & \\
\hline Cash Acq. & (5) & $\begin{array}{c}0.024 \\
(0.361)\end{array}$ & & $\begin{array}{l}-0.009 \\
(0.656)\end{array}$ & & (7) & $\begin{array}{c}0.004 \\
(0.869)\end{array}$ & & $\begin{array}{l}-0.001 \\
(0.965)\end{array}$ & \\
\hline Repurchases & (5) & $\begin{array}{c}0.030 \\
(0.035)\end{array}$ & $* *$ & $\begin{array}{l}-0.006 \\
(0.552)\end{array}$ & & (7) & $\begin{array}{c}0.024 \\
(0.068)\end{array}$ & $*$ & $\begin{array}{c}0.001 \\
(0.879)\end{array}$ & \\
\hline Dividends & (5) & $\begin{array}{l}-0.004 \\
(0.464)\end{array}$ & & $\begin{array}{l}-0.0003 \\
(0.925)\end{array}$ & & (7) & $\begin{array}{l}-0.004 \\
(0.326)\end{array}$ & & $\begin{array}{l}0.0003 \\
(0.906)\end{array}$ & \\
\hline Debt Reduction & (5) & $\begin{array}{c}0.085 \\
(0.215)\end{array}$ & & $\begin{array}{l}-0.020 \\
(0.682)\end{array}$ & & (7) & $\begin{array}{c}0.151 \\
(0.017)\end{array}$ & $* *$ & $\begin{array}{l}-0.086 \\
(0.043)\end{array}$ & $* *$ \\
\hline Cash & (6) & $\begin{array}{c}0.113 \\
(0.314)\end{array}$ & & $\begin{array}{c}0.126 \\
(0.114)\end{array}$ & & (8) & $\begin{array}{c}0.120 \\
(0.237)\end{array}$ & & $\begin{array}{c}0.182 \\
(0.007)\end{array}$ & $* * *$ \\
\hline
\end{tabular}

(continued on subsequent page) 
Table 8 reports the coefficients $\beta_{3}$ and $\beta_{7}$ for equations (5) and (7) with investment and payout policy as the dependent variable and the coefficients $\beta_{3}$ and $\beta_{7}$ for equations (6) and (8) with cash as the dependent variable. Underfund is a continuous variable measuring the level of ERISA pension underfunding (ERISA pension liabilities - ERISA pension assets) scaled by lagged assets. Post is an indicator variable equal to $1(0)$ when the quarter end date is after (before) July 6, 2012. CAPX is capital investments scaled by lagged assets. $R \& D$ is research and development expenses scaled by lagged assets. Cash Acq. is cash expenditures for acquisitions scaled by lagged assets. Repurchases is stock repurchases scaled by lagged assets. Debt Reduction is debt reduction from the statement of cash flows scaled by lagged assets. $O C F$ is cash flow from operating activities scaled by lagged assets. Cash is cash and short term investments scaled by lagged assets. Size is the natural log of the market value of equity. MTB is calculated as the market value of equity + book assets - stockholders' equity scaled by lagged assets. Leverage is the book value of long term debt scaled by lagged assets. Working Capital is current assets excluding cash - current liabilities scaled by total assets. M\&ARank is the quartile rank of the three year average of number of acquisitions by industry from SDC. MTBRank is the quartile based rank of MTB $* * *, * *, *$ - Statistically significant at the $1 \%, 5 \%$, and $10 \%$ level, respectively, using two-tailed standard errors. 


\section{Table 9: Alternative Pension Funding Relief Shocks}

$$
\begin{aligned}
& \text { Investment or Payout Policy }=\beta_{0}+\beta_{1} \text { PostPFE }+\beta_{2} \text { Underfund }+\beta_{3} \text { PostPFE } \times \text { Underfund } \\
& +\beta_{4} \text { OCF }+\beta_{5} \text { Cash }+\beta_{6} \text { Size }+\beta_{7} \text { Leverage }+\beta_{8} M T B+\varphi+\varepsilon \text {. } \\
& \text { Investment or Payout Policy }=\beta_{0}+\beta_{1} \text { PostPPA+ } \beta_{2} \text { Underfund }+\beta_{3} \text { PostPPA } \times \text { Underfund } \\
& +\beta_{4} \text { OCF }+\beta_{5} \text { Cash }+\beta_{6} \text { Size }+\beta_{7} \text { Leverage }+\beta_{8} M T B+\varphi+\varepsilon .
\end{aligned}
$$

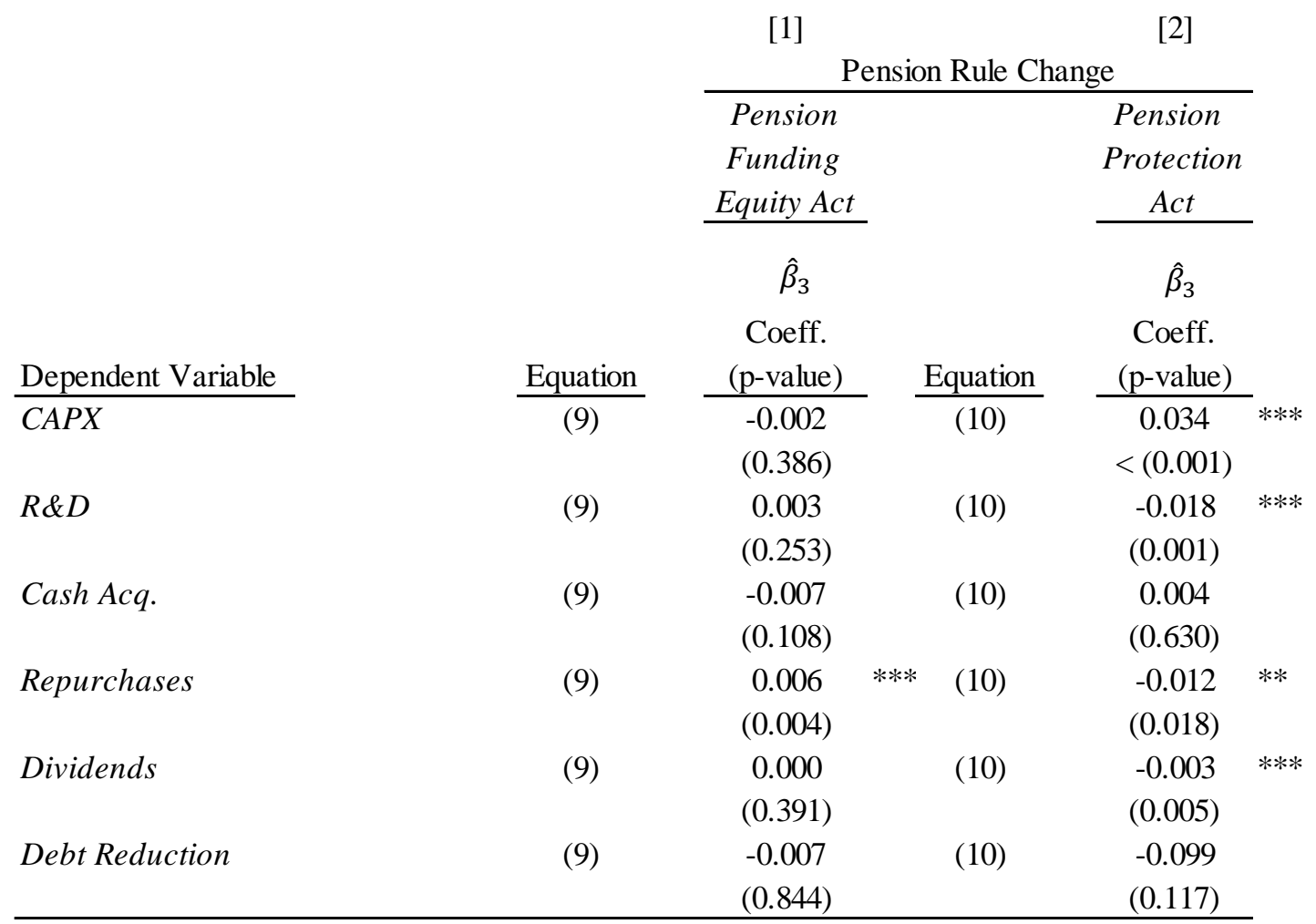

Table 9 reports the coefficient $\beta_{3}$ for equation (5) and (6) with investment and payout policy as the dependent variable. Underfund is a continuous variable measuring the level of GAAP-based pension underfunding (GAAP pension liabilities - GAAP pension assets) scaled by lagged assets. PostPFE is an indicator variable equal to 1 (0) when the quarter end date is after (before) April 12, 2004. PostPPA is an indicator variable equal to $1(0)$ when the quarter end date is after (before) December 31, 2007. CAPX is capital expenditures scaled by lagged assets. $R \& D$ is research and development expenses scaled by lagged assets. Cash Acq. is cash expenditures for acquisitions scaled by lagged assets. Repurchases is stock repurchases scaled by lagged assets. Debt Reduction is debt reduction from the statement of cash flows scaled by lagged assets. $O C F$ is cash flow from operating activities scaled by lagged assets. Cash is cash and short term investments scaled by lagged assets. Size is the natural log of the market value of equity. MTB is calculated as the market value of equity + book assets - stockholders' equity scaled by lagged assets. Leverage is the book value of long term debt scaled by lagged assets.

$* * *, * *, *$ - Statistically significant at the $1 \%, 5 \%$, and $10 \%$ level, respectively, using two-tailed standard errors. 
Figure 1: Pension Plan Funding and Pension Contributions

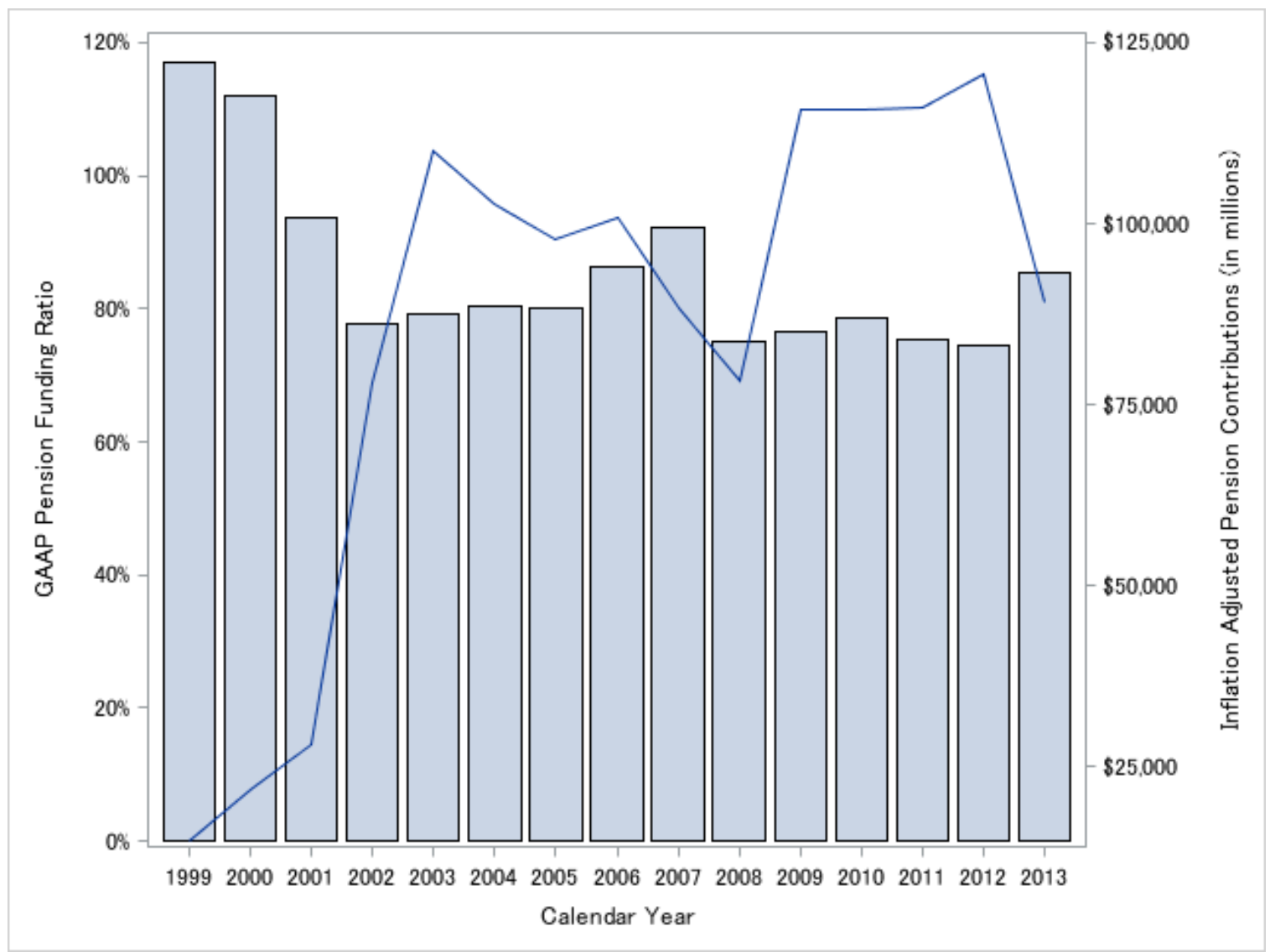

Figure 1 reports pension funding data from the Compustat - Pension Annual file from 1999 to 2013. The bars represent the average GAAP-based pension funding ratio $\left(\frac{G A A P \text { pension assets }}{\text { GAAP pension liabilities }}\right)$. The line represents total employer contributions, inflation adjusted, from defined benefit plans. 
Figure 2: ERISA Discount Rates

\begin{tabular}{|c|c|c|c|c|}
\hline Segment & Pension Liability Duration & $\begin{array}{c}\text { Pre } \\
\text { MAP- } \\
21 \\
\end{array}$ & $\begin{array}{c}\text { Post } \\
\text { MAP- } \\
21 \\
\end{array}$ & $\begin{array}{c}\% \\
\text { Change }\end{array}$ \\
\hline 1 & $\leq 5$ years & $2.0 \%$ & $5.5 \%$ & $179.8 \%$ \\
\hline 2 & 5 to 20 years & $5.1 \%$ & $6.9 \%$ & $35.1 \%$ \\
\hline 3 & > 20 years & $6.2 \%$ & $7.5 \%$ & $21.5 \%$ \\
\hline \multicolumn{5}{|c|}{$\begin{array}{l}\text { Figure } 2 \text { displays the changes in ERISA discount rates as of January } 1 \text {, } \\
\text { 2012. Interest rates increased from a two-year average of investment } \\
\text { grade bond yields (pre-MAP-21) to a } 25 \text {-year average of investment } \\
\text { grade bond yields (post-MAP-21). The interest rates are applied based } \\
\text { upon the duration of the pension liability. }\end{array}$} \\
\hline
\end{tabular}


Figure 3: Expected Change in Mandatory Contributions due to MAP-21

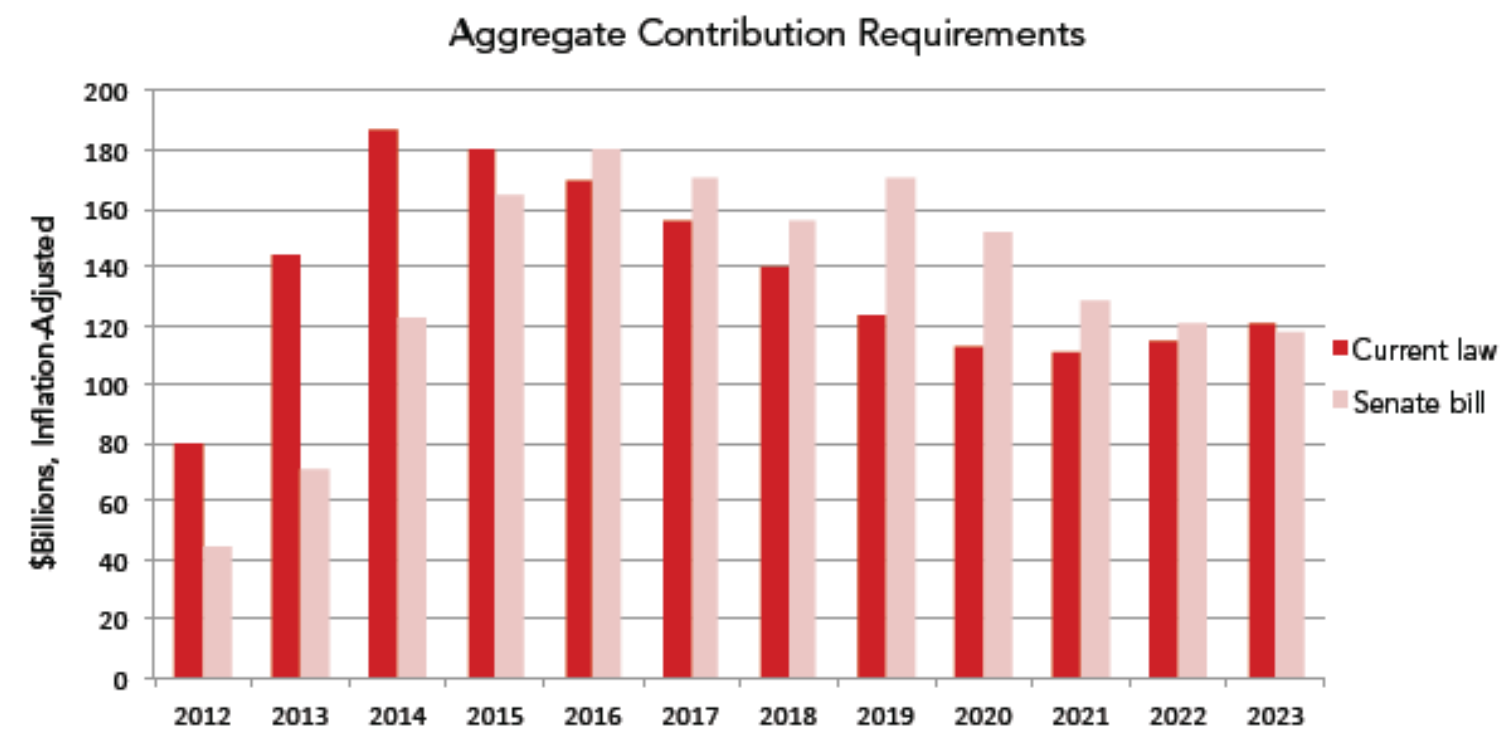

Figure 3 details the effect of MAP-21 on annual ERISA mandatory contributions. "Current law" reflects mandatory contributions before MAP-21 and "Senate bill" reflects mandatory contributions after. The Society of Actuaries expected the change in ERISA pension accounting to reduce mandatory contributions by $\$ 190$ billion through 2015 . Practitioners expected mandatory contributions to decrease by approximately 44 percent in 2012, 51 percent in 2013, 34 percent in 2014, and 8 percent in 2015 (source: Society of Actuaries, 2012). 


\title{
Figure 4: Example of MAP-21 Annual Funding Notice
}

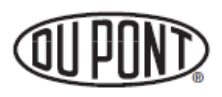

\author{
MAP-21 Supplement to Annual Funding Notice \\ Of \\ The DuPont Pension and Retirement Plan ("the Plan") \\ For \\ Plan Year Beginning January 1, 2012 and Ending December 31, 2012 ("Plan Year”)
}

\begin{abstract}
This is a temporary supplement to your annual funding notice. It is required by a new federal law named Moving Ahead for Progress in the 21st Century Act (MAP-21). MAP-21 changed how pension plans calculate their liabilities. The purpose of this supplement is to show you the effect of these changes. Prior to MAP-21, pension plans determined their liabilities using a two-year average of interest rates. Now pension plans also must take into account a 25-year average of interest rates. This means that MAP-21 interest rates likely will be higher and plan liabilities lower than they were under prior law. As a result, your employer may contribute less money to the plan at a time when market interest rates are at or near historical lows.

The "MAP-21 Information Table" shows how the MAP-21 interest rates affect the Plan's: (1) Funding Target Attainment Percentage, (2) Funding Shortfall, and (3) Minimum Required Contribution. The funding target attainment percentage of a plan is a measure of how well the plan is funded on a particular date. The funding shortfall of a plan is the amount by which liabilities exceed net plan assets. The minimum required contribution is the amount of money an employer is required by law to contribute to a plan in a given year. The following table shows this information determined with and without the MAP-21 rates to illustrate the effect of MAP-21. The information is provided for the Plan Year and for each of the two preceding plan years, if applicable.
\end{abstract}

\begin{tabular}{|c|c|c|c|c|c|c|}
\hline \multicolumn{7}{|c|}{ MAP-21 Information Table ${ }^{1}$} \\
\hline & \multicolumn{2}{|c|}{2012} & \multicolumn{2}{|c|}{2011} & \multicolumn{2}{|c|}{2010} \\
\hline & $\begin{array}{c}\text { With } \\
\text { MAP-21 } \\
\text { Interest Rates }\end{array}$ & \begin{tabular}{|c|} 
Without \\
MAP-21 \\
Interest Rates
\end{tabular} & $\begin{array}{c}\text { With } \\
\text { MAP-21 } \\
\text { Interest Rates }\end{array}$ & $\begin{array}{c}\text { Without } \\
\text { MAP-21 } \\
\text { Interest Rates }\end{array}$ & \begin{tabular}{|c|} 
With \\
MAP-21 \\
Interest Rates
\end{tabular} & $\begin{array}{c}\text { Without } \\
\text { MAP-21 } \\
\text { Interest Rates }\end{array}$ \\
\hline $\begin{array}{l}\text { Funding Target } \\
\text { Attainment } \\
\text { Percentage (FTAP) }\end{array}$ & $89.60 \%$ & $77.07 \%$ & not applicable & $80.00 \%$ & not applicable & $80.00 \%$ \\
\hline $\begin{array}{l}\begin{array}{l}\text { Funding Shortfall } \\
\text { (FS) }\end{array} \\
\end{array}$ & $\$ 1,598,573,580$ & $\$ 4,097,143,134$ & not applicable & $\$ 3,248,493,110$ & not applicable & $\$ 3,142,483,980$ \\
\hline $\begin{array}{l}\text { Minimum Required } \\
\text { Contribution (MRC) } \\
\end{array}$ & $\$ 263,633,759^{2}$ & $\$ 664,004,441^{2}$ & not applicable & $\$ 517,677,818$ & not applicable & $\$ 160,520,367$ \\
\hline
\end{tabular}

Figure 4 is the 2012 annual funding notice for Dupont's Pension and Retirement Plan. Pension plan sponsors are required to provide annual funding notices to pension plan participants, unions, and the PBGC. These notices illustrate how a pension plan's ERISA funding obligations change under MAP-21 (source: PBGC via an FOIA request). 
Figure 5: Pension Contributions, Capital Expenditures, and Stock Repurchases by Quarter (Hi UF sample)

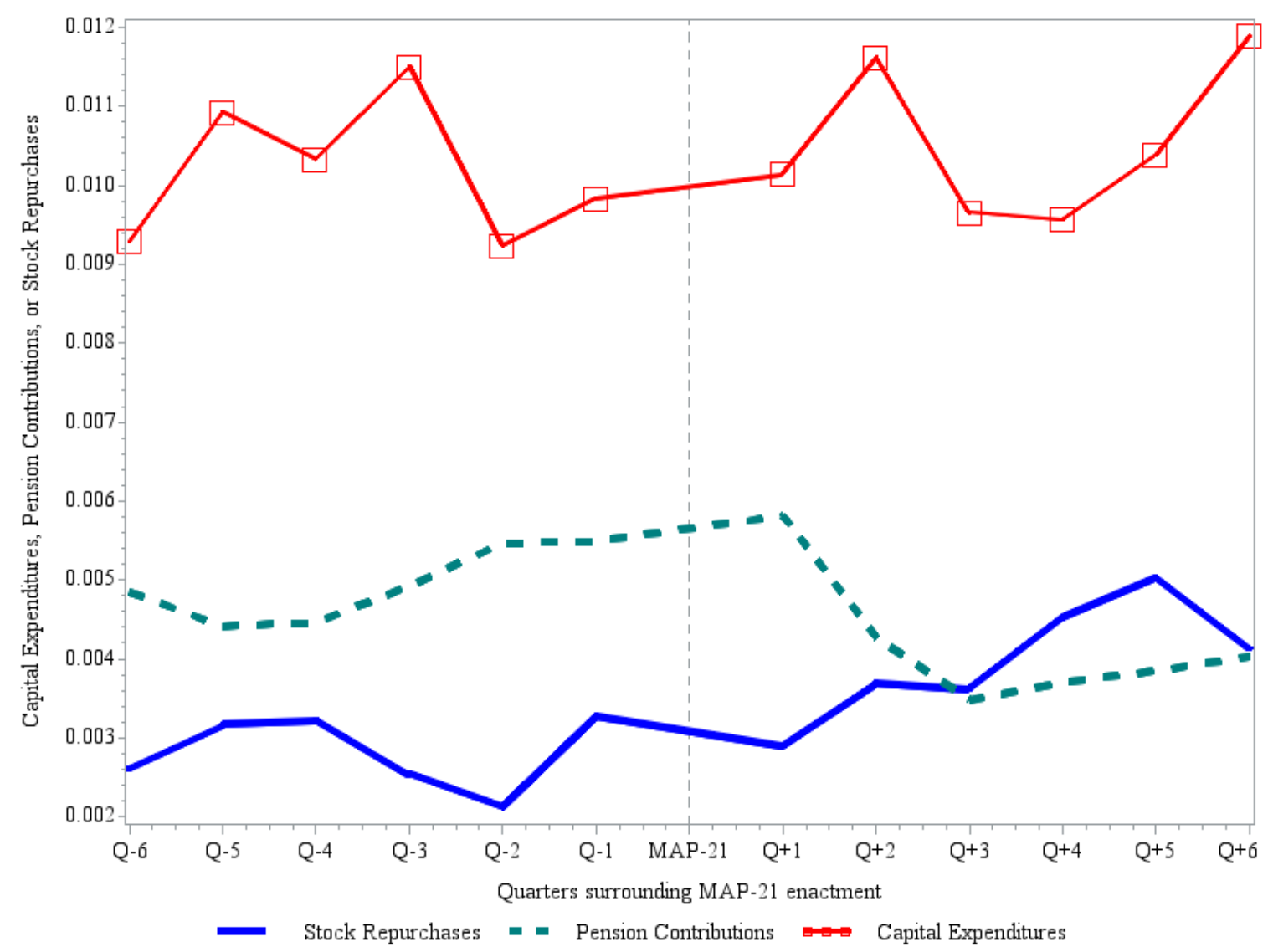

Figure 5 documents the time trend in average quarterly CAPX, Repurchases, and Pcont for the six quarters surrounding MAP-21 for the firms in the top quartile of ERISA-based pension underfunding (Hi UF). The y-axis variables are scaled by total assets. President Obama approved MAP-21 on July 6, 2012. The first pension shortfall contribution required in the MAP-21 regime was due on July 15, $2012(\mathrm{Q}+1)$. However, plans sponsors did not receive MAP-21 guidance until September 2012. Q+2 is the first full quarter in the MAP-21 regime. 